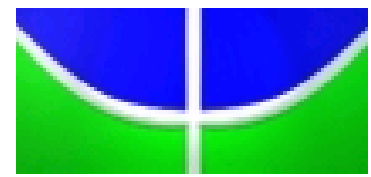

Universidade de Brasília

CET - Centro de Excelência em Turismo

Pós-graduação Lato Sensu

Curso de Especialização em Formação de Consultores em Turismo

\title{
TURISMO SUSTENTÁVEL: \\ Um Estudo Prospectivo no Município de Soure - Ilha do Marajó - PA
}

PRISCILLA COSTA DE SOUZA 


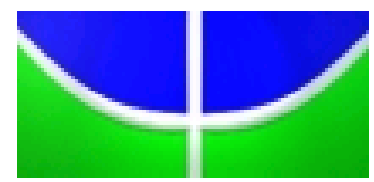

Universidade de Brasília

CET - Centro de Excelência em Turismo

Pós-graduação Lato Sensu

Curso de Especialização em Formação de Consultores em Turismo

\section{TURISMO SUSTENTÁVEL: \\ Um Estudo Prospectivo no Município de Soure - Ilha do Marajó - PA}

\section{PRISCILLA COSTA DE SOUZA}

Prof. MSc. Domingos Sávio Spezia, Orientador

"Trabalho apresentado ao Centro de Excelência em Turismo da Universidade de Brasília - CET-UnB, como requisito inicial à obtenção do Grau de Especialista em Consultoria em Turismo" 
Souza, Priscilla Costa.

\section{TURISMO SUSTENTÁVEL:}

Um Estudo Prospectivo no Município de Soure - llha do Marajó - PA/ Priscilla Costa de Souza. - Brasília, 2008.

$\mathrm{xi}, 72 \mathrm{f}$ : il.color, $29 \mathrm{~cm}$

Monografia (especialização) - Universidade de Brasília, Centro de Excelência em Turismo, 2008.

Orientador: Domingos Sávio Spezia.

1. Turismo. 2.Sustentabilidade. 3.Desenvolvimento. I. Título. 


\author{
Universidade de Brasília \\ CET - Centro de Excelência em Turismo \\ Pós-graduação Lato Sensu
}

Formação de Consultores em Turismo

\title{
TURISMO SUSTENTÁVEL: \\ Um Estudo Prospectivo no Município de Soure - Ilha do Marajó - PA
}

\section{PRISCILLA COSTA DE SOUZA}

Aprovado por:

Professor orientador: Domingos Sávio Spezia, MSc

Professor Avaliador: Gilson Zehetmeyer Borda, Dr.

Professor Avaliador: Luís Henrique Souza, MSc

Brasília, 30 de maio de 2008. 
Dedico este trabalho a minha família e ao meu noivo, pelo apoio incondicional em todos os momentos. 


\section{AGRADECIMENTO}

Agradeço a Deus por ter me dado forças, paciência e capacidade para concluir este trabalho.

A minha família pelo incentivo e apoio em todos os momentos apesar da distância.

Ao meu noivo pelo amor, apoio e compreensão da ausência necessária.

As minhas amigas Shaula e Sílvia pela ajuda e apoio durante a realização e conclusão deste trabalho.

Ao João Lima, presidente do fórum de turismo de Soure; a Maria Algina, ex gestora do departamento de turismo do SEBRAE; Dário Pedrosa ex-secretário de turismo do município de Salvaterra e Admilson Alcântara da PARATUR que contribuíram com informações muito importantes para a realização e concretização deste trabalho. 


\section{RESUMO}

Este estudo prospectivo realizado no município de Soure - Ilha do Marajó - PA buscou descrever a atual situação da atividade turística no município, para futuramente dar suporte informacional à elaboração de projetos de turismo sustentável para o local. A linha de pesquisa adotada buscou analisar a realidade do município, identificando os entraves existentes. Para tanto, foram utilizadas pesquisas descritivas e qualitativas. Durante a aplicação da pesquisa de campo, foram ouvidos alguns representantes do turismo local, onde expuseram suas opiniões e críticas em relação à atividade turística no município. Por meio de análises dos dados foi possível identificar que a implementação de projetos de turismo só será possível, após serem realizados investimentos em infra-estrutura local e ações voltadas aos aspectos sociais, ambientais e econômicos de maneira que beneficie a população residente. Através deste estudo, foi possível verificar que o turismo sustentável pode representar uma alternativa de desenvolvimento local, visto que atualmente a economia do munic ípio encontra-se baseada apenas no setor primário. A atividade turística pode ser um meio de alavancagem uma vez que pertence ao setor terciário voltado para a comercialização de serviços, e isso possibilita a dinamização do mercado local a partir da inserção de empreendimentos direcionados para o turismo.

Palavras-chave:,

1. Turismo

2. Sustentabilidade

3. Desenvolvimento 


\begin{abstract}
This work approaches the tourism activity in the county of Soure - Island of Marajó, State of Para, checking the viability of preparing a project to introduce a sustainable tourism there. The line of research was to analyze the reality of the county, identifying the clogs in it. For so much, exploratory and qualitative researches were adopted. During the field work, some representatives of the local tourism were heard, and they explained their opinions and criticisms regarding tourism activity in the county. By means of analyses of the data, it was possible to identify that the viability of projects of tourism will be only possible after investments in infrastructure and of actions turned to the economical, social and environmental aspects, so that it benefits the resident population. Tourism can represent an alternative of development, for it may inject new perspectives in the marketplace, since that, at the present, the economy of the county is based only on the primary sector. The tourist activity belongs to the tertiary sector turned to the marketing of services, and that makes possible the development of the local market through the insertion of undertakings focused on tourism.
\end{abstract}

\title{
Keywords:
}
1. Tourism
2. sustainability
3. Development 
1. INTRODUÇÃO

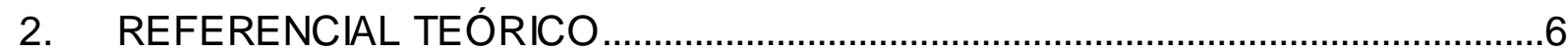

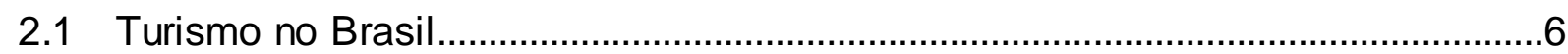

2.2 O turismo como indutor do desenvolvimento socioeconômico .............................. 11

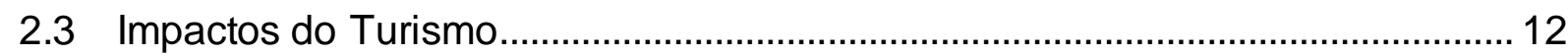

2.3.1 Impactos positivos ............................................................................... 14

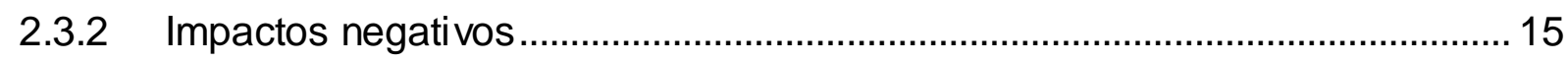

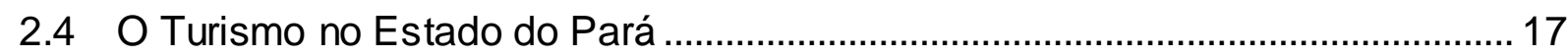

2.5 O Turismo no Arquipélago do Marajó .....................................................................21

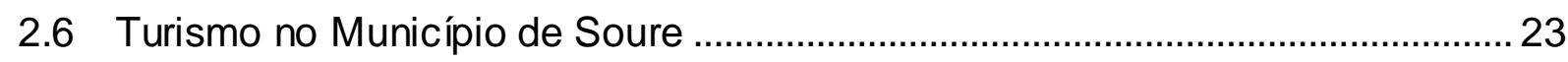

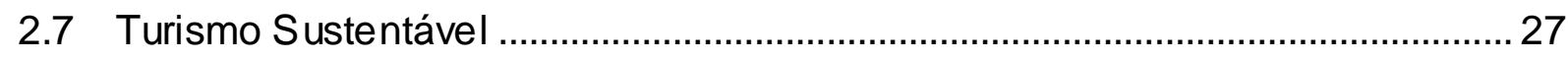

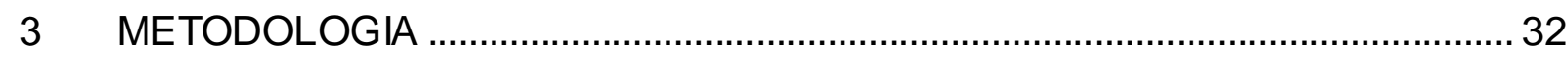

3.1 Quanto aos fins ……................................................................................ 32

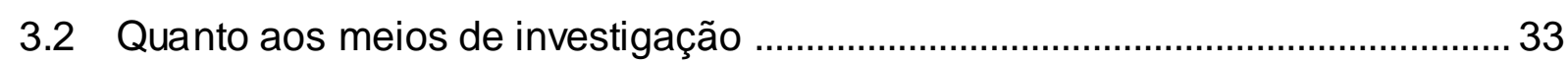

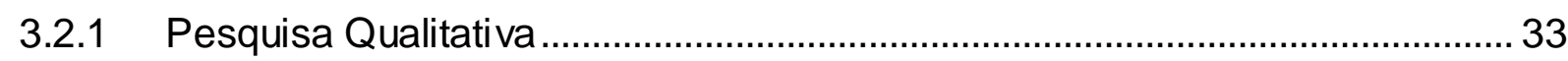

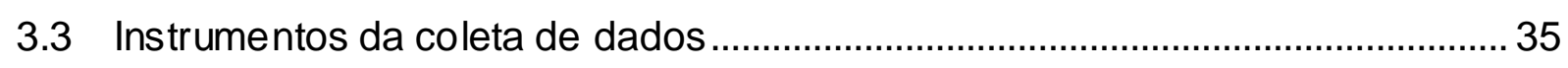

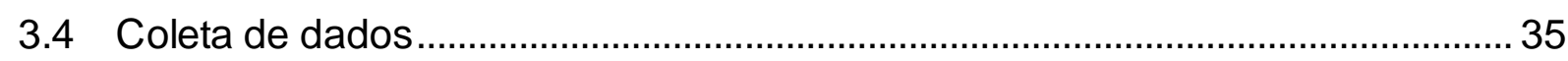

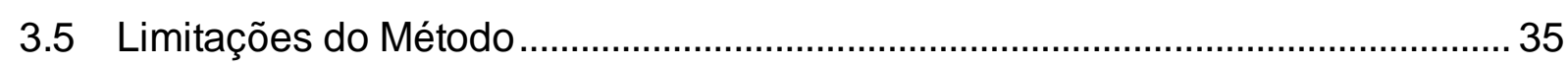

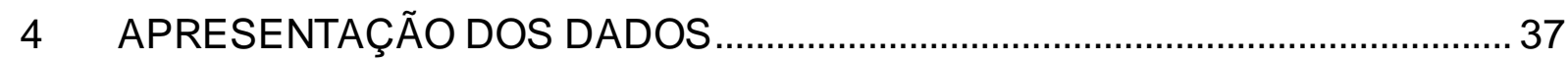

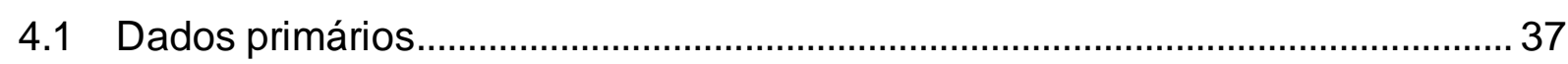

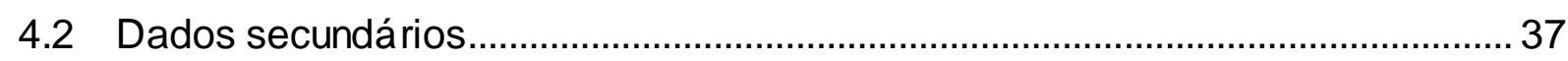

4.2.1 Perfil dos turistas que visitaram o município no ano de 2007: .........................37

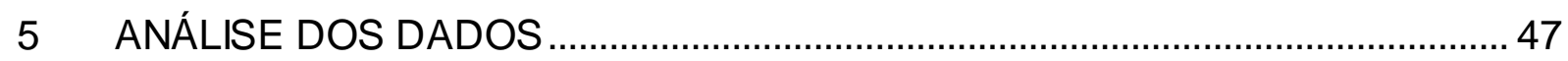

5.1 Aspectos relacionados à Infra-estrutura ………………………………….... 47

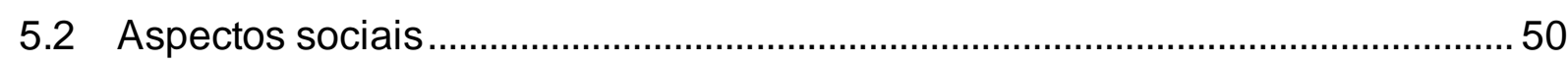

5.3 Aspectos Econômicos .................................................................................... 53

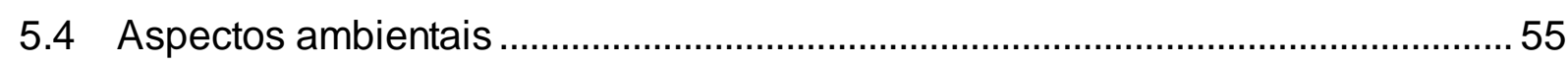

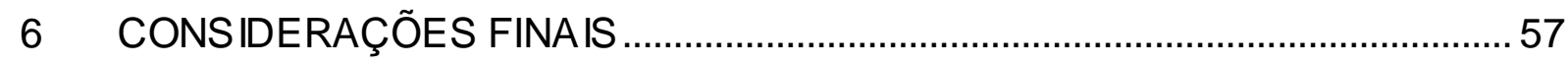

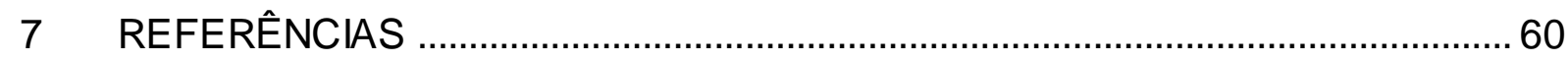

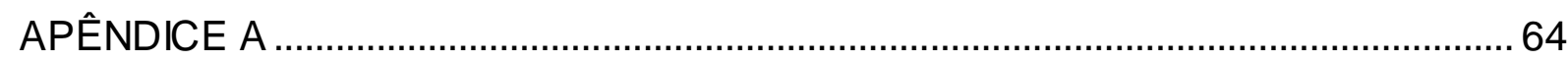




\section{INTRODUÇÃO}

O turismo ao longo dos anos vem se destacando e ganhando força no cenário nacional e internacional. Enquanto na Europa o turismo já se encontra consolidado, outros países buscam obter o diferencial para competir no mercado à preferência dos turistas que estão em busca de novas paisagens e experiências que thes ofereçam segurança, qualidade nos serviços, entre outros.

O Brasil se destaca por apresentar um forte potencial para o desenvolvimento da atividade turística no seu território, pois possui ao longo de sua extensão vários tipos de atrativos que são desde a faixa litorânea, a multiplicidade, a diversidade dos ecossistemas até a tropicalidade do clima (AULICINO, 2002).

A criação do Ministério do Turismo e a elaboração do Plano Nacional de Turismo (PNT) representaram algumas das ações estratégicas desencadeadas nos últimos anos, para a consolidação de um novo modelo de desenvolvimento da atividade turística no país (BRASIL, 2006).

As regiões brasileiras apresentam atrativos diferenciados, dentre as que mais se destacam são Nordeste, Sul e Sudeste, principalmente pela infra-estrutura de apoio que oferecem. Mas encontram-se em ascensão as regiões Centro-Oeste e Norte.

A região Norte possui um extenso território de área verde, onde pode se desenvolver o turismo voltado para a natureza (ecoturismo, turismo de aventura, pesca e etc).

O estado do Pará apresenta uma vasta diversidade de atrativos naturais e culturais. E apresenta infra-estrutura hoteleira básica. No entanto, o estado nos últimos anos está direcionando ações estratégicas para que o turismo seja viabilizado como instrumento de desenvolvimento econômico e social no território paraense.

Em decorrência da diversidade existente no Pará, a Companhia Paraense de Turismo - PARATUR dividiu o território paraense em pólos turísticos: Belém, Costa Atlântica, Tapajós, Xingu, Araguaia Tocantins e Marajó. Predominando um tipo de turismo para cada pólo (PARATUR, 2001).

O Arquipélago do Marajó possui treze municípios, mas apenas três fazem parte do pólo Marajó: Salvaterra, Soure e Cachoeira do Arari. Dentre eles foi escolhido como objeto de estudo deste trabalho o município de Soure por apresentar melhor infra- 
estrutura para a recepção e acomodação de turistas, se comparado aos demais municípios do arquipélago.

Há vários estudos sobre as potencialidades do desenvolvimento do Turismo no arquipélago do Marajó, principalmente os voltados à prática do ecoturismo, já que o território apresenta uma vasta área verde o que representa um diferencial para o destino.

A llha do Marajó possui vários atrativos turísticos. Entre eles é possível citar as praias, as trilhas ecológicas, as fazendas, os museus, os sítios arqueológicos, a produção de artesanatos feitos a partir da cerâmica marajoara e a gastronomia local. No entanto, o turismo na região não se desenvolve de maneira satisfatória. A comunidade fica excluída dos planejamentos e dos processos de decisões em relação ao turismo.

O município de Soure representa um dos principais destinos turísticos do estado do Pará freqüentado por turistas nacionais e internacionais, mas principalmente pelos Belenenses que se deslocam para Soure nas férias, fins de semana e feriados.

A duração da viagem até o município é de aproximadamente $4 \mathrm{~h}$ de barco ou balsa. Esses meios de transporte realizam viagens diariamente com saídas regulares pela manhã e pela tarde, do porto de Belém e do porto de lcoaraci, distrito de Belém.

Os barcos e as balsas que realizam o transporte para Soure não oferecem conforto para uma viagem considerada longa e cansativa. Mas, como não existe um transporte hidroviário que faça o percurso direto Belém - Soure, a viagem segue até o porto de Camará, localizado na ilha do Marajó e em seguida continua por via terrestre por meio de ônibus ou carro. Ao chegar a Salvaterra utiliza-se balsa ou um barco pequeno para atravessar o rio Paracauari, para enfim chegar a cidade de Soure. Outro meio de se deslocar para o município é através de um táxi aéreo fretado.

A infra-estrutura local básica e turística é precária. Os empreendimentos turísticos apresentam uma gestão predominantemente familiar, que está muito mais preocupada com o lucro a curto prazo do que com a qualidade dos serviços prestados ou mesmo com o desenvolvimento do turismo sustentável no município.

A população local acaba sofrendo as conseqüências de forma mais evidente, principalmente nos períodos considerados de alta estação quando o fluxo de turistas 
aumenta no município, ocasionando a falta de energia e de água que não são insuficientes para atender a demanda e a comunidade, além do aumento no preço dos alimentos e serviços há também o congestionamento dos meios de transporte, entre outras situações.

A atividade turística precisa ser analisada de forma cautelosa, pois quando inserida no cotidiano de uma localidade irá interferir de forma direta e indireta na vida da população local ocasionando impactos que dependendo da forma como o turismo foi implantado pode ter um futuro promissor ou causar danos irreversíveis.

O turismo sustentável está baseado no tripé da sustentabilidade, prioriza a preservação dos recursos naturais, sociais e culturais aliados ao crescimento econômico local.

A atividade turística interfere de forma direta na economia provocando aumento no fluxo de receitas do comércio local. No social, interfere no modo de vida da comunidade anfitriã, nos costumes e na cultura, que se não estiverem bem enraizadas provocará à perda da identidade e originalidade local e por fim, no ambiental o excesso de pessoas poderá comprometer os recursos naturais e a capacidade de carga local provocando uma incontrolável poluição dos ambientes naturais como: rios, lagos, mares, mangues o que pode a vir comprometer a saúde dos residentes e dos turistas, devido poluição da água e o excesso de lixo na cidade.

Para um município se desenvolver turisticamente é necessário estruturar um plano de desenvolvimento local, baseado na sustentabilidade, de forma que não perca suas características originais. Mas, além disso, precisa-se levar em conta que o potencial turístico de uma localidade, não é condição suficiente para tornar o município um destino turístico consolidado, antes de tudo é necessário que proporcione aos visitantes condições básicas como transporte, alojamento e alimentação, sem deixar de respeitar a população local e seus limites (BENI, 2004).

Neste estudo de prospecção do turismo no município de Soure propõe-se a seguinte questão de pesquisa: Qual a viabilidade de desenvolver Projetos de Turismo Sustentável como alternativa de desenvolvimento do município de Soure?

Este trabalho propõe um estudo prospectivo do turismo no município de Soure (PA) por meio de analises dos aspectos econômicos, sociais, ambientais e de infra- 
estrutura, com o intuito de identificar as limitações vividas pelo município que apesar de alguns investimentos na ultima década ainda não conseguiu se consolidar como um destino turístico no cenário brasileiro. Abordará também a importância do planejamento local, para ressaltar os impactos do turismo, buscando minimizar os pontos negativos e maximizar os benefícios para o município e a comunidade, ressaltando a importância de um projeto de turismo sustentável como alternativa de desenvolvimento local, baseado nos princípios da sustentabilidade.

Dessa forma, para responder a estas questões, o objetivo geral deste trabalho é realizar uma prospecção da situação turística atual do município de Soure (PA) visando fornecer informações básicas e preliminares para a implementação de futuros projetos de turismo sustentável em Soure.

Os objetivos específicos são os seguintes: (i) coletar e analisar dados referentes aos aspectos econômicos, sociais, ambientais e de infra-estrutura, para viabilizar a aplicação de Projetos de Turismo Sustentável; (ii) ldentificar os aspectos positivos e negativos que o turismo atual está proporcionando à região; (iii) gerar subsídios à elaboração de projetos de desenvolvimento do turismo no município, para órgãos do governo e da iniciativa privada.

Para a construção deste trabalho foram utilizadas as técnicas: investigação exploratória, descritiva, pesquisa bibliográfica e aplicada (pesquisa de campo). $\mathrm{Na}$ pesquisa de campo realizada no período de 26 /01 a 29/01/2008 foram feitas entrevistas com perguntas abertas e semi-estruturadas com três representantes do turismo no município.

Esta monografia está estruturada e organizada em oito partes. Na primeira e segunda partes abordam-se os aspectos conceituais da atividade turística no Brasil, enfatizando a importância do turismo como propulsor do desenvolvimento sócioeconômico local e a preocupação com os impactos gerados por ele, caso não haja um planejamento eficiente. Em seguida aborda-se o turismo no estado do Pará, na Ilha do Marajó e no município de Soure. Logo em seguida o referencial teórico aborda o turismo sustentável como uma alternativa de desenvolvimento para o município de Soure. Na terceira parte apresenta-se a metodologia utilizada para o desenvolvimento deste estudo de pesquisa, quanto aos meios de investigação e o instrumento de coleta de dados utilizados durante a pesquisa de campo no 
município de Soure. A quarta parte aborda a apresentação dos dados secundários, obtidos na Companhia Paraense de Turismo - PARATUR, referentes ao perfil dos visitantes e dos atrativos existentes no município. Na quinta parte, são analisadas as entrevistas coletadas na pesquisa de campo no município de Soure, E por fim na sexta, sétima e oitava partes são apresentadas as considerações finais, as referências bibliográficas e o apêndice respectivamente. 


\section{REFERENCIAL TEÓRICO}

\subsection{Turismo no Brasil}

O turismo é fruto da sociedade industrial e das conquistas sociais. O período anual de descanso dos trabalhadores foi conquistado com os direitos trabalhistas e vem sendo aproveitado, de forma crescente para a realização de viagens, o que contribuiu para o crescimento da atividade turística (CONTI, 2002).

O desenvolvimento do turismo no Brasil começa a ganhar destaque na década de 70. Com a industrialização o Brasil viveu seu momento desenvolvimentista, que dotou o país de um sistema viário extenso. A crescente urbanização e o surgimento da classe média de profissionais liberais completaram o quadro propício para a implantação do turismo no país (LEONY, 2002).

Simultaneamente a este período, as operadoras e agências de viagens passaram a se estruturar e difundir o turismo como uma opção para fugir da rotina. Os vôos charters e os pacotes turísticos conduziram milhares de pessoas as mais remotas partes do mundo e a localidades nos próprios paises emissores, estimulando o turismo doméstico (RUSCHMANN, 1997).

No Brasil as regiões sul e sudeste foram as que mais se destacaram e sofreram com a expansão desenfreada do turismo em seus territórios provocando sérios problemas envolvendo a degradação ambiental, social e cultural, já que a população não estava preparada e detinha pouco conhecimento sobre a atividade turística e suas conseqüências (RODRIGUES, 1996)

A partir dos anos 80, aumentou o turismo na região Nordeste, principalmente em Porto Seguro, Salvador, Recife e Fortaleza. O Nordeste passa a ser vendido como o novo Caribe. Os governos estaduais investiram em seus territórios, e estimularam à vinda de investidores estrangeiros, que injetaram divisas para a construção de grandes hotéis e resorts, principalmente próximo às áreas litorâneas, equiparados aos grandes centros turísticos internacionais. Este fato provocou o aumento dos fluxos de demandas tanto interna como externa na região (RODRIGUES, 1996)

Entretanto, ao invés de oferecer subsídios para o desenvolvimento qualitativo e durável das localidades onde foram implantados, os projetos de turismo apresentaram efeitos contrários e provocaram o aparecimento de problemas sociais 
e ambientais de toda ordem como, por exemplo, a ocupação desenfreada das áreas próximas ao litoral brasileiro ocasionando a super concentração de pessoas e de infra-estrutura turística em algumas localidades (SILVEIRA, 2000).

Além da região Nordeste, no mesmo período, a Amazônia entra no cenário turístico brasileiro para dinamizar a oferta dos produtos turísticos, com o turismo voltado para a natureza (RODRIGUES, 1996).

No início da década de 90, o país viveu profundas crises econômicas. A moeda brasileira foi desvalorizada, de forma que não era possível definir uma política econômica consistente (RODRIGUES, 1996).

Entretanto, no mesmo período cria-se a Política Nacional de Turismo - PLANTUR, que visava disciplinar a atividade turística no setor público e privado de acordo com o novo modelo econômico neoliberal implantado no país.

O PLANTUR apesar de ter apresentado objetivos bem formulados, baseados na diversificação da oferta de produtos turísticos, no aumento da geração de empregos e numa melhor distribuição de renda regional, não conseguiu obter êxito para se firmar devido algumas falhas no planejamento e na execução das políticas (RODRIGUES, 1996).

Após a implantação do plano real, a economia brasileira voltou a se estabilizar o que proporcionou um novo crescimento do mercado turístico no país. A população passou a ter maior poder de compra, e desta forma, pôde planejar melhor os gastos com turismo (FERRE IRA, 2008).

Após esse período de estabilidade proporcionado pelo plano real, o Brasil passou por novas transições, a mudança da política cambial e a desvalorização da moeda brasileira contribuíram para tornar o país um atrativo barato para os estrangeiros. $\mathrm{E}$ no mesmo período a Empresa Brasileira de Turismo - EMBRATUR intensificou a divulgação dos produtos turísticos no exterior.

As instituições responsáveis pelas políticas de turismo no Brasil passaram a desenvolver novos projetos como PNMT - Programa de Nacional de Municipalização do Turismo e o Programa Nacional de Ecoturismo, baseados na sustentabilidade para contribuir com o crescimento e aperfeiçoamento da atividade turística no país. 
Desde então, o turismo no Brasil continua crescendo aliado a uma maior oferta de produtos turísticos e melhorias da infra-estrutura de acesso aos estados brasileiros. A construção e reforma das estradas e aeroportos para atender a crescente demanda principalmente na região Norte e Nordeste do país, a implantação de novas rotas aéreas e preços mais acessíveis de pacotes turísticos, estimularam o crescimento do turismo doméstico no país (MARTINS, 2007).

Em 2004, com a criação e a elaboração do Plano Nacional de Turismo o país buscou um novo posicionamento para ganhar mercado. Procurou organizar roteiros com diferentes tipos de atrativos, contemplando as diversidades das regiões brasileiras, através das políticas de turismo que visam desvincular a imagem do turismo de massa (Sol e mar) do país. O turismo brasileiro inicia uma nova fase.

O Plano Nacional de Turismo compreende sete macros programas. O Programa de Regionalização do Turismo - Roteiros do Brasil é um deles, busca a descentralização e a interiorização da atividade adequando-se as diversidades regionais do país, propondo um novo posicionamento dos produtos turísticos brasileiros no mercado.

O Brasil mesmo que de forma tímida, esta se tornado um mercado turístico competitivo, pois, nos últimos anos procurou investir e se adequar às exigências do mercado. Entretanto, o país detém um enorme atraso histórico no setor, o que dificulta o avanço da atividade, os investimentos ainda não foram suficientes para tirar o país de posições modestas no ranking mundial de turismo (MENDES, 2007).

Atualmente, segundo a OMT, o Brasil é o $36^{\circ}$ principal destino do mundo em números de visitantes e o $39^{\circ} \mathrm{em}$ faturamento. Para avançar nessa lista, o país terá que superar grandes desafios relacionados à infra-estrutura, aos transportes e as vias de acesso (rodovias, malhas aéreas) (MENDES, 2007).

De acordo com o relatório de Competitividade em Turismo e Viagens, elaborado pelo Fórum Econômico Mundial (World Economic Fórum - WEF), em relação aos potencias naturais e culturais, rede de transportes, infra-estrutura e o medo da violência; Brasil ocupa a $38^{\mathrm{a}}$ posição entre os mais atraentes para os turistas internacionais (O Estado de S.Paulo, 2007).

Este fato representa um fator negativo para o crescimento da atividade turística no país, questões referentes à segurança e a infra-estrutura devem ser priorizadas 
pelos órgãos responsáveis. Mas, é um alerta de que o país precisa investir em segurança e infra-estrutura, para, de fato se tornar um destino atrativo. A atividade turística no Brasil é bastante promissora, mas precisa de ajustes para se consolidar.

Embora, o Brasil apresente condições favoráveis para o crescimento de novas atividades que constituem o turismo, devido à diversidade de recursos naturais, culturais e geográficos presentes ao longo da extensão territorial do país, o modelo turístico predominante ainda é o convencional, baseado na construção de grandes centros turísticos, na concentração de empreendimentos, no turismo de massa e no fortalecimento de centros tradicionais de recepção do turismo, particularmente voltados para (DIAS, 2003).

A elaboração de planos e um gerenciamento eficiente da atividade turística farão com que os impactos negativos, sejam minimizados e a atividade seja rentável e benéfica para o país, para a sociedade atual e para as gerações futuras. Além, da grande contribuição da atividade para o país, não só no fator econômico, mas também nas ações que irão influenciar os meios sociais e ambientais.

O Brasil passa por um momento de transformação e redescoberta de seus valores. Mas, deve-se levar em consideração que a atividade turística se mostra muito sensível aos fatores externos, o que provoca grandes oscilações ao longo dos anos. Os problemas sociais e econômicos como a violência, variação do dólar, crises econômicas, terrorismo e recentemente o caos aéreo influenciam de forma direta no desaceleramento do turismo no Brasil.

Para o turismo se consolidar definitivamente como uma política de estratégia de crescimento para o país, é necessário adotar e implementar políticas com base em processos de desenvolvimento planejado e articulado destinado a transformar matéria prima em produtos competitivo (CARVALHO, 2007).

Para Beni (2004 p.84) "a competitividade de uma destinação turística depende da capacidade do setor de inovar e melhorar permanentemente a qualidade de sua oferta." Caso contrário, o turismo no local cumprirá o ciclo ascensão, desenvolvimento e declínio.

A busca pela competitividade deve obedecer a um critério de produção para diferentes áreas e setores, de modo que os produtores apresentem efetivas vantagens locacionais. Cada região ou município deve procurar espaços de 
competitividade de acordo com suas condições e potencialidades (BUARQUE, 2006).

A Região Norte ainda busca seu espaço como destino turístico brasileiro, apresenta como forte atrativo estar localizada na Amazônia, despertando interesses em todo o mundo pela rica biodiversidade e ecossistema presentes em seu território.

A região vem se tornado um dos principais destinos dos turistas estrangeiros conforme dados do Departamento de Polícia Federal, constituindo outra porta de entrada de estrangeiros no país, além dos principais pólos São Paulo, Rio de Janeiro e região Nordeste (MARTINS, 2007).

No entanto, a distância dos grandes centros emissores do país, o difícil acesso, o número reduzido na venda, a pouca oferta de produtos turísticos no mercado e preços pouco competitivos aliados a carência de infra-estrutura de uma maneira geral, prejudica o crescimento da demanda turística na região.

Apesar das ações desenvolvidas nos últimos anos, ainda não foi suficiente para consolidar os produtos turísticos da Região Norte no mercado nacional e internacional, pois, existem fatores externos como: a distância geográfica e econômica dos lugares de mercado emissor; o sistema de transporte, as formas de comercialização dos operadores, concorrência com outros centros turísticos nacionais que comprometem o desenvolvimento do turismo na região (BOULLÓN, 2005).

Não é suficiente apenas possuir diferenciais turísticos, planejar o espaço, implantar o equipamento, ter qualidade nos serviços, é necessário que o produto final dessa oferta agregada seja efetivamente competitivo (BENI, 2000).

Nenhum núcleo receptor sobrevive apenas de atrativos, pois estes são consumidos pelos turistas como se fosse uma mercadoria. O turismo é um produto intangível, que está no imaginário dos visitantes, tudo que ele irá levar do local visitado são lembranças, e essas podem ser boas ou ruins.

O turismo quando não planejado para residentes locais e monitorado para identificar seus impactos, não poderá se consolidar como um produto turístico nacional e nem internacional, pois ficará saturado e logo será deixado de lado como aconteceu em outras localidades brasileiras, que vivem hoje um declínio da atividade turística. É 
fundamental criar uma base de sustentação, sem criar uma dependência da atividade para o núcleo receptor.

O Brasil tem tudo para constituir-se como um pólo mundial de turismo voltado para a natureza, com a exploração (preferencialmente sustentável), pois possui belezas naturais, culturais e ecossistemas que perdura o ano todo, nas cinco regiões brasileiras. (DIAS, 2003).

Com ações voltadas para a consolidação dos roteiros regionais, o Brasil poderá competir por igual com outros países, que não possuem a dimensão territorial e a matéria prima existente no país, mas, por uma questão de gestão, investimentos e profissionalismo, estão no patamar dos países mais requisitados mundialmente.

\subsection{O turismo como indutor do desenvolvimento socioeconômico}

O Brasil é um país em desenvolvimento que recentemente descobriu no turismo a possibilidade de crescimento. Na atual economia multifacetada, o turismo quando corretamente implementado é cada vez mais visto como uma das principais fontes para a geração de desenvolvimento socio-econômico em uma região (SANTOS, 2006).

A atividade turística é considerada atualmente um dos setores da economia que mais cresce. No entanto, o desenvolvimento de uma região, ou produto turístico, sem planejamento, baseado apenas em estudos econômicos, pode levar rapidamente, ao esgotamento dos recursos naturais, à descaracterização do patrimônio cultural e à desestruturação social. (BRASIL, 2006).

O turismo poderá ser considerado uma alternativa de crescimento econômico, pois os aumentos da oferta de produtos turísticos e dos serviços influenciarão no aumento do Produto Nacional Bruto. E por ser uma atividade típica do setor terciário, que engloba serviços de vendas como: transporte, hospedagem, eventos, lazer e entretenimento, culturais, etc., é considerada produtiva, geradora de renda e que provoca indiretamente acentuadas repercussões econômicas em outras atividades produtivas através do efeito multiplicador (BENI, 2004).

O exemplo disso acontece quando o turista chega ao núcleo receptor e utiliza de forma direta os transportes, os meios de hospedagem e alimentação. De forma 
indireta estão os fornecedores de alimentos para restaurantes, os distribuidores de bebidas, o comércio como um todo, principalmente aqueles relacionados com 0 comércio de produtos artesanais.

Os bancos e toda a gama de empresas que atuam na região também geram produtos que serão consumidos pelos turistas e atuam indiretamente na atividade ou que recebem de forma induzida seus efeitos (LEMOS, 2005).

O turismo provoca o desenvolvimento intersetorial, em função do efeito multiplicador dos investimentos e dos fatores de crescimento da demanda interna e receptiva. É considerado excelente para a obtenção de melhores resultados no que diz respeito ao desenvolvimento e planejamento regional e territorial (BENI, 2004).

O aumento da oferta turística dentro de um território estimula no mercado a inserção de novos empreendimentos voltados para alimentação, hospedagem, diversão, entre outros, faz com que cresça a oferta de emprego local, pois são gerados novos postos de trabalho. E mesmo que de forma tímida provoca alterações no poder aquisitivo dos residentes, repercutindo na diminuição da mão de obra desempregada.

O setor público também se beneficia da atividade turística, através da arrecadação de impostos diretos e indiretos incidentes sobre a renda gerada na cadeia produtiva local (BENI, 2004).

No entanto Santos (2006 p.21) alerta que, não se pode priorizar a esfera econômica em detrimento das demais, mas há que se contemplar o conjunto. No turismo é comum associá-lo ao crescimento econômico, mas esta análise é um equivoco, pois é necessário analisar o conjunto econômico-social e ambiental antes de implantar atividade turística no local, de forma que os impactos negativos sejam minimizados.

\subsection{Impactos do Turismo}

O turismo por ser considerado uma atividade recente e dinâmica, ainda está descobrindo seus reais impactos. Por isso precisa ser constantemente analisado, ordenado e avaliado por meio de um conjunto de indicadores (positivos e negativos) 
que não priorizem apenas o lucro, mas também o social e o ambiental para que seja compreendido e monitorado de maneira satisfatória (LEMOS, 2005).

A atividade turística pode ter elevada importância sobre o nível econômico de uma localidade, desde que, haja uma correta medição dos impactos provocados pelo turismo. Esses impactos são em decorrências da grande diversidade de segmentos relacionados com a atividade turística de maneira direta ou indireta (transportes, hospedagem, alimentação, entretenimento, comunicação, entre outros) (BRASIL, 2006).

O setor turístico pode agregar benefícios ou alguns transtornos para a comunidade envolvida. Entretanto se a atividade for bem planejada e gerida, os efeitos positivos tendem a serem superiores aos negativos. Mas, quando a atividade é mal planejada, há uma probabilidade maior de gerar mais problemas do que ganhos para a população residente (BRASIL, 2006).

Por alguns anos a atividade turística foi estimulada pelo governo como sendo uma alternativa às crises que estavam ocorrendo no país. Desta forma, o turismo não foi planejado e nem possuia pessoas capacitadas para atuar na área.

Em virtude disso, muitos locais estimularam o turismo e acabaram desencadeando sérios problemas sociais. Hoje, alguns destinos turísticos brasileiros encontram-se saturados de empreendimentos, como grandes redes de hotéis, resorts, restaurantes, lojas de artigos voltados para turistas, entre outros, resultando em uma oferta maior que a demanda, ocasionando sérios impactos negativos para o local.

Mas, o turismo não tem só os aspectos negativos, desde que planejado e organizado, poderá proporcionar as comunidades receptoras benefícios, nos aspectos sociais, econômicos e ambientais.

De acordo com Beni ( 2004), a atividade turística trará benefícios quando estiver associada uma economia bem planejada, na qual deverá haver cooperação e coordenação entre o setor público e privado. O governo é responsável pelas obras de infra-estrutura fundamentais ao desenvolvimento do turismo e a iniciativa deve oferecer serviços turísticos de qualidade. 


\subsubsection{Impactos positivos}

Alcançar resultados positivos com a atividade turística só será possível através de estruturas que não estejam concentradas apenas no aspecto econômico, mas também nos aspectos ambientais e nas necessidades locais (SINGH e SINGH, 2002)

O turismo é capaz de gerar um número expressivo de repercussões nas localidades onde a atividade é introduzida. Em seguida são relacionados os mais relevantes:

a) geração de novas ocupações para os residentes

Os empregos gerados pelo turismo não são apenas os diretos, como hotéis e restaurante, mas também os indiretos representados pelos produtores locais, agricultura, pesca, artesanato, entre outros. Para o município de Soure, o turismo irá promover novas fontes de renda, já que sua economia está baseada na agricultura de subsistência e na pecuária, sendo que a última encontra-se em decadência.

Além do que, os empregos gerados pelo mercado turístico exigem que os empregados aprendam novas tecnologias com o uso do computador e desenvolvam habilidades que possibilitem o desenvolvimento dos recursos humanos locais, estimulando uma mão de obra mais qualificada (OMT, 2003).

b) geração e aumento da renda local

A expansão salarial gerada pela atividade turística no município amplia o poder aquisitivo da população residente, advindo da atividade turística, melhorando o padrão de vida, com a circulação de mais receitas no comércio local, proporcionando maior poder de compra.

c) ampliação na arrecadação de impostos locais

O turismo gera impostos que poderão ser convertidos em recursos para melhorar as instalações, serviços e a infra-estrutura local. As construções de novas vias de comunicação beneficiarão os turistas e a população residentes, além das melhorias nos sistemas de comunicação: telefones, televisão, etc. aumentando a necessidade de prestadores de serviços para o atendimento ao turista (DIAS, AGUIAR, 2002). 
d) implantação de infra-estrutura

Lugares que apresentam potencial para o turismo tendem a receber melhorias na infra-estrutura básica e de apoio ao turismo, beneficiando a população residente; as atrações culturais passam a ser mais valorizadas, com eventos programados para atrair turistas em determinadas épocas do ano, possibilitando aumento da oferta de trabalho para os residentes e a dinamização da economia local (DIAS, AGUIAR, 2002).

\subsubsection{Impactos negativos}

Da mesma forma, que possui um elevado número de benefícios, a atividade turística também traz consigo problemas que podem ser de significativa gravidade em conseqüência da ineficiência do planejamento turístico.

O turismo é uma atividade que deve ser pensada a longo prazo, logo os resultados que beneficiarão a comunidade demoram mais para serem visualizados e usufruído por todos. Os impactos negativos do turismo são mais numerosos e apresentam resultados mais rápidos do que os positivos. Os impactos negativos mais relevantes são:

a) aumento exagerado do fluxo de turistas

A literatura sobre impactos sociais do turismo observa que o excesso de habitantes temporários (turistas) de alguma forma intervém no meio ambiente natural e humano dos residentes, na medida em que territórios são constantemente desmatados para a construção de resorts ${ }^{1}$ e os rios são represados para prática de esportes náuticos. (BRASIL, 2006).

\footnotetext{
Resorts são hotéis situados fora das áreas metropolitanas, em áreas especialmente aprazíveis, com atividades especiais de recreação para hóspedes de lazer. Essas instalações podem incluir balneários aproveitando as paisagens da região e os recursos naturais. São numerosos à beira-mar, mas ocorrem também à beira de lagos, rios, na serra, nas altas montanhas e na região rural. De formas arquitetônicas variáveis, têm sistemas de refeições geralmente na base de pensão completa ou meia-pensão. São usuais piscinas, jardins, grandes espaços de natureza, onde são oferecidas diversões e esportes diversos. (MTur, 2000)
} 
Gera, também, congestionamentos nas vias de acesso e conflitos entre a população local e os turistas, principalmente na alta estação, pois nesse período o intenso fluxo de turistas modifica completamente o cotidiano e os hábitos da comunidade anfitriã.

b) elevação do custo de vida local

O fluxo turístico desordenado provoca um processo no qual os habitantes locais são levados a se desfazerem de suas terras e se excluírem dessa expansão, o que caracteriza um processo de desterritorialização e de conseqüente exclusão, devido o aumento da especulação imobiliária que acaba expulsando os residentes locais para a construção de hotéis, centros de lazer, alimentação entre outros referentes à atividade turística (BRASIL, 2006).

O aumento no preço das mercadorias de alimentos e vestuário também excluem a comunidade dos benefícios que poderiam ser gerados pela atividade turística, além de que provoca problemas de ordem econômico-social, contribuindo para o aumento da violência, prostituição entre outros.

c) desinteresse dos turistas pelo local

Quando uma localidade fica saturada com a atividade turística, os turistas optam por não mais visitá-la. A cidade fica abandonada, os hotéis fecham devido à grande oferta e pouca demanda ocasionando o desemprego. A necessidade de consumo estimulada pelo poder de compra que o turismo havia possibilitado diminuiu provocando impactos na economia local.

Brasil (2006 p. 20) define que o turismo desordenado, sem a preocupação com a sustentabilidade provoca:

\footnotetext{
"a sobrecarrega da infra-estrutura de água, luz, telefonia, esgoto e transporte de toda a coletividade de cidadãos de uma destino turístico, cuja qualidade de vida pode ser impactada pela poluição ambiental, sonora e visual que a atividade turística produz. Congestionamento no trânsito, crescimento da violência,da prostituição e da exploração sexual infanto juvenil,processos de exclusão social, economica e cultural, aumento dos preços de itens básicos da alimentação, maior consumo de água, luz e aumento na produção de lixo têm se configurado como questões recorrentes e impactantes, em áreas turísticas brasileiras e mundiais."
}

Faz-se necessário acompanhar o desenvolvimento do turismo, estruturando e ordenando o fluxo de turistas de acordo com sua capacidade de carga, baseando-se em um plano preventivo que considere a necessidade de informar e conscientizar pessoas. Caso contrário, os turistas irão embora, deixando de freqüentar o espaço, 
que perdeu suas características originais visto antes como um atrativo, conseqüentemente os visitantes irão em busca de novos lugares (BRAGA, 2007).

d) destruição do meio ambiente natural e dos aspectos culturais.

O contato com a natureza constitui, atualmente, uma das maiores motivações das viagens de lazer. No entanto devem ser avaliados os efeitos negativos, evitando-os para que se preserve o valioso patrimônio local, impedindo uma degradação irremediável (RUSCHMANN, 1997).

As conseqüências em termos ecológicos e culturais serão incalculáveis, pois o turismo uma vez inserido no território sem planejamento adequado poderá levar a destruição dos seus recursos naturais e a devastação da paisagem local, podendo até provocar na comunidade receptora um sentimento avesso a atividade turística, pois iriam sentir-se estrangeiros em seu próprio território vendo os usos e costumes locais sacrificados na ânsia de trazer divisas para a região (CASTELLI, 2001).

\subsection{O Turismo no Estado do Pará}

O Estado do Pará está localizado na Região Norte do país, possui uma área de 1.247.689,5 Km² aproximadamente, com uma população de 7.110 .465 (estimativa de 2006 do IBGE $^{2}$ ). A capital paraense é a cidade de Belém, ponto de partida para conhecer os outros municípios do estado.

O Pará apresenta recursos com grandes potenciais para a realização da atividade turística, desde recursos naturais (rios, ilhas, lagos, praias, floresta amazônica, flora e fauna, etc.), recursos culturais (patrimônio histórico, artístico e monumental, numerosas etnias indígenas e quilombos, artesanato, folclore) até manifestações culturais vivas de grande notoriedade, como é o caso do Círio de Nazaré em Belém e o Festival do Çairé, no município de Santarém além da gastronomia paraense (PARATUR, 2001).

O turismo no Pará iniciou efetivamente na década de 70 com a criação da Companhia Paraense de Turismo - PARATUR, a qual passou a representar o

2 Disponível em http://www.ibge.gov.br/cidadesat/default.php 
instrumento necessário para fomentar o setor no estado, através de ações direcionadas à implantação de projetos turísticos, assim como para criar prioridades nos programas dos governantes locais e regionais (CRUZ, 1998).

$\mathrm{Na}$ década de 80, o turismo no estado apresentava-se em fase de crescimento. E no final da década de 90 , início de 2000 , as políticas públicas voltadas para o desenvolvimento do turismo nos estado foram intensificadas.

Em 2000 foi lançado o Programa de Desenvolvimento do Ecoturismo para Amazônia Legal - PROECOTUR, vinculado às ações do governo federal, com recursos do Banco Interamericano de Desenvolvimento - BID e do Governo Federal (CRUZ, 1998).

O PROECOTUR abrange nove estados da Amazônia legal: Acre, Amapá, Amazonas, Maranhão, Mato Grosso, Pará, Rondônia, Roraima e Tocantins e tem por objetivo o desenvolvimento da região amazônica por meio do ecoturismo, maximizando os benefícios econômicos, sociais e ambientais para a comunidade receptora (CRUZ, 1998).

No estado do Pará foram implementadas diretrizes de uso do território, de acordo com o que consta no Plano de Desenvolvimento do Turismo do Estado do Pará PDTEP no qual, o estado foi dividido em seis pólos de desenvolvimento: Belém, Costa Atlântica, Marajó, Tapajós, Araguaia Tocantins e Xingu, em função das características diferenciadas de recursos e de demanda presentes nos pólos.

Apesar, do estado do Pará possuir grande potencial turístico e um forte apelo comercial por ser considerado a porta de entrada da Amazônia, ainda precisa melhorar e se estruturar, pois, dispor de bons recursos não é condição suficiente para se constituir em um destino turístico competitivo.

É condição necessária para recepcionar os turistas disponibilizar serviços com qualidade no setor de hospedagem, alimentação, transportes além de qualificar profissionais e investir na infra-estrutura local, rodoviária, aérea e hidroviária, já que para alguns municípios do interior o acesso somente é possível por vias fluviais.

O Pará possui $4.215 \mathrm{~km}$ de rodovias asfaltadas o que para seu tamanho é uma extensão ainda muito pequena. Além disso, a grande pluviosidade da região torna a manutenção desta rede muito dispendiosa e várias rodovias têm sua trafegabilidade 
afetada nos períodos de chuvas mais intensas. Por esta razão, o transporte hidroviário é o mais utilizado na Região Amazônica. (PARATUR, 2001)

Apesar da rede hidrográfica paraense ser uma das maiores do mundo, a sinuosidade dos rios e obstáculos naturais tornam as viagens fluviais demoradas, dificultando certos segmentos de demanda que dispõem de pouco tempo para viagens dentro do estado (PARATUR, 2001).

Situações desse tipo são comuns na llha do Marajó e no município de Soure, pois os turistas chegam a Belém, e querem conhecer a ilha, no entanto, esse deslocamento é demorado, não é possível ir e voltar no mesmo dia, devido à viagem ser longa e cansativa, levando em média 4 horas entre a travessia de barco e o percurso do ônibus até chegar ao destino final.

Os turistas que não dispõe de muito tempo acabam desistindo de conhecer o Marajó e optam por lugares mais próximos da capital. Isso se torna um ponto desfavorável para o crescimento do turismo no município e no estado, visto que, grande parte dos municípios encontram-se distante da capital paraense Belém.

Os empreendimentos turísticos no Pará se desenvolvem de maneira desordenada e desequilibrada no território paraense. Mais da metade (54\%) das ofertas comercializadas pelas operadoras paraenses predominam na cidade de Belém e seus arredores mais próximos. A oferta de serviços e produtos turísticos é pequena e extremamente concentrada em poucos destinos e empreendimentos (PARATUR, 2001).

Essa concentração na capital e nos seus arredores prejudica o desenvolvimento do turismo no estado, pois um estado que apresenta um território tão extenso e que poderia ser aproveitado para o desenvolvimento da atividade turística fica limitado, conseqüentemente as ofertas comercializadas são reduzidas, se comparado a outros estados com territórios menores, mas que apresentam uma gama de ofertas e serviços turísticos mais qualificados.

A estrutura empresarial do setor turístico paraense enfrenta dificuldades por ser dispersa e atomizada. A maioria das empresas (hotéis, operadoras...) são de pequeno porte e de propriedade familiar, movimentam, salvo algumas exceções, volumes de negócios reduzidos (PARATUR, 2001). 
Entretanto, este cenário está começando a mudar após a inauguração do Centro de Convenções da Amazônia - HANGAR que ocorreu em 2007. Muitos investidores foram atraídos para a cidade de Belém, principalmente do setor hoteleiro. Grandes cadeias internacionais estão se inserindo no mercado Paraense. De acordo com informações contidas no jornal local, há uma perspectiva de nove construções no setor de hospedagem até 2009 na cidade.

Na ilha do marajó também há construções de hotéis, não chegam a ser de cadeias, mas são de investidores estrangeiros que visitaram a região, gostaram do local e acabaram comprando imóveis para investir no setor de hospedagem (MARAJÓ, 2007).

Esses fatos comprovam que o Pará tem um grande potencial a partir do momento que tiver uma infra-estrutura hoteleira consolidada, meios de transportes seguros e confortáveis, poderá se tornar um destino turístico competitivo no cenário nacional.

De acordo com Freire (16/01/2008) Presidente da Associação Brasileira da Indústria de hotéis - $\mathrm{ABIH}$, em entrevista concedida ao jornal local, "o turismo no estado do Pará é imbatível, o estado reúne tudo que um turista gosta: sol, praias, cultura, gastronomia, arte, música, teatro tudo com qualidade e uma oferta diferenciada, além da religiosidade e a Amazônia, no entanto, todo esse apelo ainda não é suficiente, falta um trabalho mais consistente e sistematizado com informações mais completas do que o estado tem a oferecer" (FRE IRE, 2008).

O Estado do Pará representa um dos mais importantes da Região Amazônica, por seu destacado papel na economia da região, não pode ficar alheio aos processos de desenvolvimento do turismo e as novas tendências impostas pelo mercado. É imprescindível acompanhar o processo, de forma sustentável, preocupado em preservar os recursos naturais, culturais e a qualidade de vida da população local.

O PNT 2007/2010 define como visão do plano "contemplar as diversidades regionais proporcionando a expansão do mercado interno e a geração de produtos marcados pela brasilidade" (BRASIL, 2007).

Dentro do plano de turismo vale destacar "os destinos que se adaptarem melhor às orientações do mercado e apresentarem com êxito as características geográficas e singularidades, relativas à paisagem, cultura, patrimônio e serviços, terão mais sucesso na consolidação da atividade".(BRASIL, 2007). 
Baseada nesta perspectiva de crescimento e de oportunidade para os novos destinos, que o estado do Pará competirá como um destino que une os recursos naturais da Amazônia, as manifestações culturais e a gastronomia local.

O desenvolvimento do turismo resultará no aproveitamento da vocação e aptidão do estado e da llha do Marajó, pois, a partir do momento que constituírem elementos necessários de infra-estrutura, aliados a fatores naturais e culturais para receber turistas nacionais e internacionais, terá condições de competir no mercado como um destino turístico consolidado.

\subsection{Turismo no Arquipélago do Marajó}

A ilha do Marajó encontra-se localizada na parte oriental, extremo norte do Estado do Pará, apresenta como limites ao norte o Estado do Amapá e o Oceano Atlântico; ao Sul o rio Pará; a leste a baía do Marajó; e a oeste o Estado do Amapá, corresponde a cerca de 4,7\% do Estado do Pará (LIMA, et. al,2005).

Distante $80 \mathrm{~km}$ da capital Belém, constitui-se numa das mais ricas regiões do país em termos de recursos hídricos e biológicos (BRASIL, 2007).

A Ilha foi descoberta pelo espanhol Vicente Pizón e batizada como llha Grande de Joanes, recebeu em 1754 o nome Marajó, em tupi significa "barreira do mar" (BRASI, 2007).

O arquipélago é formado por 13 municípios e um conjunto de ilhas constituindo a maior ilha fluvial do mundo, com $49.606 \mathrm{Km}^{2}$ aproximadamente é considerado um dos principais pólos ecoturisticos da Amazônia (BRASIL, 2007).

A Ilha do Marajó é uma das principais referências quando se fala de turismo no estado do Pará, destaca-se pela diversidade da paisagem formada por florestas, campinas, gramados, praias, lagos, furos e igarapés, além da fauna que apresenta rica variedade. Esses recursos colocam o Marajó numa condição privilegiada para a prática do turismo (O PANTANAL, 2000).

A população total dos municípios que compõe a região, de acordo com a estimativa do IBGE de 2005 era de 418.160 habitantes o equivalente a $6,5 \%$ da população paraense (BRASIL, 2007). 
A densidade demográfica é bastante reduzida cerca de 4 habitantes $/ \mathrm{Km}^{2}$. Da mesma forma condizente com uma estrutura econômica essencialmente primária. A taxa de urbanização é muito baixa, de apenas 38,8\% em 2000, ou menos da metade da média nacional, ou seja, cerca de $61 \%$ da população local reside nas áreas rurais (BRASI, 2007).

A estrutura econômica de todos os 13 municípios que compõem a llha do Marajó é essencialmente primária, baseando-se no extrativismo vegetal, na pesca, na pecuária extensiva e na agricultura de subsistência (BRASIL, 2007).

O PIB de toda a região em 2003 correspondia a 853 milhões de reais, apenas 2,9\% do PIB total do Pará. O PIB per capita representa $24 \%$ do PIB per capita médio do país (BRASIL, 2007).

A atividade pecuária possui uma forte expressão na economia local, apesar de ter sofrido uma redução nos últimos anos. A razão principal dessa decadência é o grande atraso técnico da atividade, na região. As fazendas necessitam de investimentos em equipamentos, tecnologias e profissionais capacitados para ter um produto competitivo no mercado nacional (BRASIL, 2007).

No entanto, representam uma tendência consolidada no Marajó, pois são consideradas centenárias. As atividades de turismo rural e ecoturismo estão aumentando gradativamente à medida que as fazendas estão se preparando para o turismo rural, investindo na divulgação das propriedades rurais e oferecendo serviços peculiares referentes ao cotidiano da fazenda (ILHA DO MARAJÓ, 2003)..

Dessa forma, os proprietários procuram suprir a decadência da pecuária, com a atividade turística, abrindo suas propriedades para visitas e serviços de hospedagem e alimentação, procurando adequar sua estrutura para oferecer serviços com qualidade. As fazendas sempre foram destinos turísticos, mas só recentemente começaram a ser formatadas como produtos da atividade turística, vendidos por operadoras, locais nacionais e internacionais (ILHA DO MARAJÓ, 2004).

A llha do Marajó apesar de ser formado por 13 municípios, somente Soure e Salvaterra se destacam e oferecem uma estrutura de transporte, hospedagem e alimentação. Os demais, apesar de possuírem atrativos naturais, encontram-se em uma posição desfavorável, quanto a sua localização e acesso. Além de que, não oferecem infra-estrutura básica e turística satisfatórias. 
A atividade turística apresenta um grande potencial de desenvolvimento para a região, que atualmente possui a economia baseada no setor primário. O turismo poderia ser uma opção para dinamizar a economia local, fortalecendo o setor de serviços.

\subsection{Turismo no Município de Soure}

O município de Soure está localizado a leste da ilha de Marajó, no estado do Pará. Distante $87 \mathrm{Km}$ em linha reta e $94 \mathrm{Km}$ em linha fluvial, da capital Belém. É originário de antiga aldeia dos índios Marauanás. Considerado o maior município do arquipélago marajoara. Encontra-se situado na margem esquerda do rio Paracauari e é conhecido como a pérola do arquipélago. (CRUZ, 1998)

O município possui uma área de aproximadamente $3.520 \mathrm{~km}^{2}$. E apresenta os seguintes limites: ao norte, Oceano Atlântico, rio Amazonas e o município de Chaves; a leste, a Baia do Marajó; ao Sul, o município de Salvaterra; a oeste o município de Cachoeira do Arari (PARATUR, 2001).

O clima é predominantemente quente úmido (média $27^{\circ} \mathrm{C}$ ) na na maior parte do ano. Apresenta períodos de chuvas abundantes, no período de janeiro a maio. De setembro a dezembro há predomínio de seca e o período restante é considerado de transição. (PARATUR, 2001)

De acordo com o censo do IBGE a população total do município era de 21.395 de habitantes. Com uma área de $3.512,86 \mathrm{~km}^{2}$, representando 0,28\% do Estado, 0,09\% da Região e 0,04 \% de todo o território brasileiro (IBGE, 2008).

O município apresenta como bases de sustentação econômica o extrativismo, a pecuária, o comércio e a agricultura, sendo a pecuária a principal atividade econômica do município, seguida pela pesca. (PARATUR, 2001)

A partir das décadas de 70 e 80, instalaram-se com mais freqüência alojamentos do tipo pousadas, financiados com recursos da Superintendência de Desenvolvimento da Amazônia - SUDAM para a construção e operacionalização de empreendimentos hoteleiros. Dentro de uma política de desenvolvimento para a Amazônia, Soure foi 
escolhida como uma das cidades com "vocação natural" para o turismo. (FIGUEIREDO, 1998).

Esse ato representou o início de nova etapa para o desenvolvimento do turismo no em Soure. Os investimentos do governo militar através da SUDAM, da EMBRATUR, e de órgãos estaduais e municipais estimularam a dinamização da atividade turística e a construção de empreendimentos voltados para hospedagem e alimentação. Modificando o cenário social do Marajó, predominante de fazendeiros, com a entrada de empresários de turismo e de turistas (FIGUEIREDO, 1998).

Após a criação do plano de turismo da Amazônia, as agências de viagens e o setor hoteleiro começaram a organizar e divulgar o destino Marajó. Posteriormente, foi criado o Plano de Desenvolvimento para o estado do Pará, no qual foram criados os pólos.

A partir de então várias atitudes foram tomadas para que o turismo crescesse e desenvolvesse no município. No entanto as ações propostas pelo poder público nas últimas décadas ainda não foram suficientes, apesar de estarem teoricamente corretas, o que ocorre na verdade é uma tentativa retórica de usar o turismo bandeira para a promoção política, muito comum na região (CRUZ, 1998).

Mas a atividade turística não pode ser vista como a solução para os problemas econômicos e sociais do município. Precisa ser levada a sério por seus governantes, pois o turismo quando estimulado em um município que não se encontra preparado para a inserção de mais agentes econômicos, para a utilização adequada dos recursos naturais e culturais, tendem a sofrer conseqüências negativas e às vezes até irreversíveis para a população residente.

O município de Soure esta incluído como destino de férias da população de Belém, a qual representa o maior fluxo de turistas para o município. E está entre os destinos turísticos mais procurados do Estado.

O acesso ao município de Soure pode ser feito via transporte hidroviário ou aéreo. 0 hidroviário é o mais usado, por ser economicamente mais acessível. Três empresas oferecem esse serviço, realizando viagens diárias com saídas nos períodos da manhã e da tarde, do porto de Belém, galpão 10 da CDP. Todas possuem frotas de barcos e balsas. 
Os barcos e balsas saem em direção ao porto de Camará, em Joanes. Em seguida a viagem continua por via terrestre, através de ônibus ou vans até o município de Salvaterra, outras seguem de barco até Soure. O transporte entre os municípios de Soure e Salvaterra é realizado por balsas ou pequenos barcos que fazem a travessia no rio Paracauari que divide os dois municípios. O transporte aéreo conta com seis empresas que operam um sistema de frete (MARTINS, 2005).

Os horários podem variar de acordo com a demanda e o período, como por exemplo, nos fins de semana, feriados prolongados e nas férias de julho, considerado o período de alta estação no Estado, e coincide com o clima menos chuvoso, típico da região, tornando os passeios mais acessíveis e proveitosos para os visitantes.

"Soure é conhecida como a Pérola do Marajó ou Capital do Marajó", situa-se historicamente como referencial do turismo no local. É o município que apresenta o melhor padrão de hospedagem ao turista, se comparado aos outros do arquipélago (MARAJÓ, 2000).

O município possui uma infra-estrutura turística formada por nove estabelecimentos de hospedagem classificados entre hotel e pousada, oito hotéis-fazendas e seis estabelecimentos de alimentação, de acordo com as tabelas 1 e 2 a seguir:

Tabela 1 - Estabelecimentos de Hospedagem, Unidades Habitacionais e Leitos

\begin{tabular}{|c|c|c|c|c|c|c|}
\hline \multicolumn{2}{|c|}{ Estabelecimentos } & \multicolumn{2}{|l|}{ Cadastrados } & \multicolumn{3}{|l|}{ Não cadastrados } \\
\hline Números & & $\begin{array}{l}\text { Unidades } \\
\text { Habitacionais } \\
\text { (UH) }\end{array}$ & $N^{\circ}$ de leitos & $\begin{array}{l}\text { Números de } \\
\text { estabelecimentos }\end{array}$ & $\begin{array}{l}\text { Unidades } \\
\text { Habitacionai } \\
\text { s (UH) }\end{array}$ & $\begin{array}{l}\mathrm{N}^{\circ} \text { de } \\
\text { leitos }\end{array}$ \\
\hline Hotéis & 2 & 49 & 105 & 5 & 64 & 186 \\
\hline Fazendas & 8 & 42 & 126 & & & \\
\hline
\end{tabular}

Fonte: Soure. Secretaria de Turismo ${ }^{3}$

Tabela 2- Estabelecimentos de restaurantes e capacidade de assentos

\begin{tabular}{l|l}
\hline Estabelecimentos & Número de Assentos \\
\hline 7 & 510 \\
\hline
\end{tabular}

Fonte: Soure. Secretaria de Turismo

3 Informação verbal obtida da Secretaria de Turismo de Soure em 2008 
Entretanto, apesar do município de Soure apresentar melhor infra-estrutura turística, estar localizada em área privilegiada pela natureza e receber um grande fluxo de visitantes nos meses de janeiro, fevereiro, julho e nos feriados prolongados, 0 município ainda carece de investimentos, pois para o turismo, é necessário algo mais do que paisagens naturais e culturais, são necessários equipamentos e serviços especializados que atendam às pessoas residentes e aos turistas (CRUZ, 1998).

Para Boullón (2005 p. 8) "a hospedagem, o transporte, a alimentação e a diversão são elementos que compreendem um conjunto de necessidades, que facilitam a prática das atividades turísticas no núcleo receptor".

Sem infra-estrutura e equipamentos adequados fica difícil o crescimento do turismo no local. O turista precisa sentir segurança, confiabilidade e conforto para querer retornar ao destino turístico.

Apesar do município apresentar problemas referentes à infra-estrutura e transporte, possuir recursos naturais que merecem destaque como: as praias, os mangues, os rios e as fazendas. De acordo com as informações obtidas na Secretaria de Turismo, Soure possui quatro praias: Garrote, Araruna, próxima a área de mangue, Barra Velha e Pesqueiro, a mais freqüentada e distante do centro urbano, $13 \mathrm{~km}$.

O acesso às praias é através de ônibus, táxi ou moto-táxi, muito comum na região, sendo que a praia do Pesqueiro é a única que possui um transporte oferecido pela prefeitura, um ônibus que sai diariamente do centro as $08 \mathrm{~h}, 12 \mathrm{~h}$ e $18 \mathrm{~h}$, a passagem custa $R \$ 1,50$.

Os outros atrativos típicos da região são as fazendas, que buscam retratar o cotidiano do caboclo marajoara, a culinária e o artesanato local, feito a partir da cerâmica marajoara.

Segundo Boullón (2005 p. 8) os atrativos turísticos são a base funcional de um município turístico e representa a matéria prima, sem a qual é impossível pensar em desenvolvê-los turisticamente. Os municípios estão condicionados pela presença e quantidade de atrativos, naturais, culturais, entre outros.

Elevar a quantidade de investimentos turísticos de um município é condição necessária, mas não suficiente para a elaboração de um plano diretor, que explicite claramente as ações a serem tomadas e a detenção de informações referentes as 
tendências turísticas, que se encontram em ascensão, a fim de planejar um desenvolvimento turístico capaz de atender as expectativas dos turistas, oferecendo serviços com qualidade (BRASIL, 2006).

O município de Soure apresenta um enorme potencial turístico do ponto de vista dos atrativos naturais. Mas é preciso avaliar criteriosamente estes recursos, antes de se transformar em matéria prima para o turismo, com o objetico de prevenir uma possível degradação do meio social e ambiental.

\subsection{Turismo Sustentável}

Este trabalho considera a compreensão da sustentabilidade, ponto central para a obtenção de uma visão macro do turismo. As reais possibilidades, riscos, limites e tendências da atividade dentro do município de Soure.

De acordo com a Comissão mundial da ONU sobre o meio ambiente e desenvolvimento (UNCED), a qual apresentou um documento chamado Our Common Future, mais conhecido como relatório Brundtland, define que o "desenvolvimento sustentável", está condicionando o crescimento presente ao não comprometimento do crescimento futuro (ECONOMIANET, 2008)

No Brasil, ao longo das últimas décadas, esta ocorrendo uma transformação no modo de vida das pessoas que residem em grandes cidades. Cresce a busca por áreas naturais, que permitem um maior contato com a natureza e a cultura local.

No entanto, as administrações municipais não estavam preparadas para atender essa demanda, e autorizaram a construção de empreendimentos em áreas naturais, acarretando um desenvolvimento desordenado que provocou sérios problemas de degradação ambiental e social, algumas vezes até irreversíveis (DIAS, 2002).

A atividade turística se desenvolveu de forma bastante rápida, utilizando de forma intensiva os recursos naturais, sem uma preocupação com a preservação dos atrativos, que constituem a base de sustentação da atividade (DIAS, 2002).

Os municípios que buscaram o turismo como uma alternativa de desenvolvimento, mas que não realizaram um planejamento para a implantação da atividade, enfrentam um processo de saturação e destruição dos seus recursos, tanto naturais 
como culturais, causados pelo excesso de capacidade de carga, falta de planejamento e controle eficaz.

De modo equivocado, por vezes, sugere-se que o turismo sustentável seja simplesmente outro tipo de turismo, sinônimo de ecoturismo e antítese do turismo de massa. Mas a sustentabilidade refere-se a todos os tipos de turismo, mesmo porque em todos os atrativos locais os recursos utilizados e consumidos são produtos da atividade turística (BRASIL, 2006).

O desenvolvimento do turismo sustentável está intrinsecamente ligado ao processo de mudança, o que torna indispensável à necessidade de monitoramento permanente, permitindo um acompanhamento e uma avaliação continua para determinar sua eficiência (DIAS, 2002).

A Organização Mundial do Turismo - OMT, (2003, p. 24) define o desenvolvimento sustentável do turismo da seguinte forma:

"É um processo contínuo que requer monitoramento constante dos
impactos que a atividade pode causar, de modo que, com ações de
manejo, seja possível minimizar os impactos negativos e maximizar os
benefícios potenciais, introduzindo medidas preventivas ou de correção de
rumo. Requer a participação e o comprometimento de todos os atores
envolvidos com a atividade, onde o lucro deve ser distribuído de forma
eqüitativa entre os promotores da atividade e a população local".

O turismo está relacionado com o meio ambiente e com o bem-estar social local, o desenvolvimento do turismo sustentável depende da conservação dos recursos naturais, sem eles a localidade deixa de ser atrativa e passa a não mais receber turistas. Além de que, a identidade cultural deve ser mantida e valorizada pela população residente, para que não sofra descaracterização com a influência dos turistas, substituindo seus valores culturais, pelas culturas estrangeiras, chegando ao ponto de alterar seus atrativos, costumes em função do mercado, da geração de divisas para tornar-se um produto padrão.

Segundo a OMT, (2003 p. 30) os parceiros para o desenvolvimento do turismo sustentável são: o trade turístico, os apoiadores ambientais e a comunidade local. Esses grupos podem e devem trabalhar juntos a fim de planejar ações benéficas, para que o turismo se torne uma alternativa para o núcleo receptor.

O processo de produção deve ser sustentável para que a atividade turística tenha continuidade, ou seja, preservar os recursos naturais e os valores sociais e culturais 
do município, portanto a decisão de investir na atividade turística deve priorizar uma gestão sustentável (LEMOS, 2005).

Os núcleos receptores que começaram a explorar o turismo de qualquer forma sem se preocupar com análises de viabilidade para obtenção de informações referentes à capacidade de carga do município, os impactos gerados, as conseqüências para os residentes, hoje encontram-se descaracterizados e com graves problemas sociais e ambientais.

Soure é uma cidade que apresenta muitos atrativos que podem ser utilizados pelo turismo desde que sejam de forma sustentável. Entretanto, é necessário respeitar o limite de carga suportável pelo local, além de preparar a comunidade e os empresários locais para conviverem com o turismo. O convívio pode até parecer pacífico agregando apenas ações benéficas, contudo é importante destacar que o turismo provoca muitos conflitos internos que precisam ser administrados e monitorados com eficiência para não gerar problemas mais graves.

Dentro do Programa de Regionalização do Turismo é destacada a importância da sustentabilidade nos aspectos econômicos, sociais e ambientais como requisitos básicos para a inserção de produtos turísticos com maior qualidade e capacidade competitiva. Desse modo a sustentabilidade desses aspectos deve transparecer, durante o desempenho das atividades envolvidas com o turismo no município (BRASIL, 2006)

A conservação da atratividade dos recursos turísticos é uma condição indispensável para o desenvolvimento sustentável do turismo. Sem os atrativos fica difícil torná-lo um destino turístico, a não ser que sejam criados atrativos superficiais capazes de atrair demandas (MAGALHÃES, 2002).

RUSCHMANN (1997 p.80), afirma que o planejamento da evolução do turismo, através do enfoque do desenvolvimento sustentável da atividade, apresenta-se como a forma preventiva ideal para a proteção dos meios visitados conservando a natureza, oferecendo conforto e satisfação ao turista sem agredir a originalidade das comunidades receptoras.

Apenas ações que visam um desenvolvimento sustentável da atividade turística poderão ser favoráveis para os empreendedores, populações locais, turistas e destinos turísticos (RUSCHMANN, 1997). 
O turismo é uma atividade que pode ser inserida em um município como uma alternativa de desenvolvimento e crescimento da economia local. Desde que, seja feito de forma organizada e planejada atendendo as necessidades da população residente, sem excluí-los do processo e muito menos impondo o turismo como única alternativa.

A vontade em desenvolver a atividade turística deve partir dos interesses das pessoas que residem no local, caso contrário, o turismo deixará de ser uma oportunidade e passará a constituir um fracasso como é o caso de alguns municípios brasileiros que não se preocuparam em desenvolver um turismo sustentável e encontram-se atualmente abandonados e com problemas sociais e ambientais, conseqüentemente deixam de ser atraente para os turistas.

No entanto, os mais prejudicados são as pessoas do núcleo receptor que passam a conviver com as degradações deixadas pela atividade. É preciso buscar o apoio da comunidade desde o início da organização territorial destinada a impulsionar o turismo. É um processo difícil, mas é imprescindível para alcançar resultados satisfatórios para o desenvolvimento sustentável do turismo no local (MAGALHÃES, 2002).

A educação e conscientização do turista sobre os impactos, somadas as práticas sustentáveis e socialmente responsáveis com a adoção de um código de conduta ética nos destinos turísticos são ações imprescindíveis para que o turismo possa ter um desenvolvimento sustentável de longo prazo (BIN, 2007).

Os programas deveriam focar não apenas os turistas, mas também o aumento da qualidade de vida da população local. Quando os residentes dividirem os lucros (benefícios) da atividade turística passarão a ser defensores dos recursos naturais e culturais do seu município (SCHLUTER, 2002).

Uma das tendências para as destinações turísticas é procurar atrair formas mais sustentáveis de turismo, que minimizem os custos e maximizem os benefícios para a comunidade local (SWARBROOKE, 2000).

O turismo representa hoje um poderoso instrumento de desenvolvimento capaz de participar ativamente de qualquer estratégia, de que sejam utilizadas ações sustentáveis (DIAS, 2003). 
O turismo e os municípios brasileiros só têm a ganhar com a junção da sustentabilidade e a atividade turística. Dessa forma, será possível obter um turismo organizado e estruturado com uma política econômica voltada para a ação de programas e projetos com o intuito de implementar atitudes favoráveis ao turismo. Respeitando a capacidade de carga do território, as pessoas que nele habitam, sem prejudicar a qualidade de vida. Dessa maneira será possível reduzir os impactos advindos da atividade e aumentar os benefícios utilizando como base os princípios da sustentabilidade. 


\section{METODOLOGIA}

A metodologia aplicada a esta monografia foi baseada nos conceitos metodológicos de Vergara (2007), e nos conceitos de métodos e técnicas de pesquisa do autor Richardson (1999).

\subsection{Quanto aos fins}

Para Vergara (2007 p.46) os fins da pesquisa podem ser classificados como: exploratória, descritiva, explicativa, metodológica, aplicada e intervencionista. E este trabalho foi caracterizado como uma investigação exploratória, explicativa e aplicada.

A pesquisa exploratória possibilita um maior conhecimento sobre o tema ou problema da pesquisa, por isso é apropriada para áreas que há pouco conhecimento acumulado sobre o assunto e onde a compreensão do problema por parte do pesquisador, ainda são insuficientes ou inexistentes (VERGARA, 2007).

O município de Soure objeto da pesquisa não possui informações suficientes sobre o turismo no local. Pouco se fala do turismo como uma alternativa de desenvolvimento local, baseado na sustentabilidade. É com este intuito que este trabalho procurou elaborar um diagnóstico do município e propor o turismo sustentável como uma alternativa de desenvolvimento local

Para Vergara (2007 p.47) a pesquisa explicativa "tem como principal objetivo tornar algo inteligível justificar-Ihes os motivos. Visa, portanto, esclarecer quais fatores contribui de alguma forma para a ocorrência de determinado fenômeno".

Através da pesquisa explicativa foi possível obter informações sobre os reais problemas que ocorrem no município, em relação à segurança, transporte e infraestrutura.

Segundo Vergara (2000 p.47), a pesquisa aplicada "é fundamentalmente motivada pela necessidade de resolver problemas concretos, mais imediatos, ou não. Tem, portanto, finalidade prática, ao contrário da pesquisa pura, motivada pela curiosidade intelectual do pesquisador". 
Através deste instrumento, que é motivado pela necessidade de resolver problemas, foi possível formular questões referentes aos problemas do município, com o objetivo de diagnosticar, esclarecer e buscar soluções para os entraves.

Dessa forma, obteve-se a opinião dos representantes da esfera pública e privada do município, a respeito do turismo e da importância da atividade como alternativa de desenvolvimento sustentável local.

\subsection{Quanto aos meios de investigação}

Para Vergara (2007 p.50) os meios de investigação podem ser pesquisa de campo, pesquisa de laboratório, documental, bibliográfica, experimental, ex post facto, participante, pesquisa-ação e estudo de caso. Nesta monografia forma realizadas pesquisas documentais, bibliográfica e de campo.

a) Pesquisa documental na Companhia paraense de Turismo- PARATUR, na Secretaria de Turismo de Soure e no Fórum de Turismo de Soure. Nesses locais, foram encontrados dados estatísticos, informações pertinentes ao turismo no município, referentes aos serviços de hospedagem e alimentação e inventários turísticos.

b) Pesquisa bibliográfica em livros, revistas especializadas, jornais, internet, dissertações com dados pertinentes ao turismo e a sustentabilidade.

c) Pesquisa de campo foi realizada no município de Soure, com representantes do turismo local.

\subsubsection{Pesquisa Qualitativa}

A abordagem qualitativa é uma opção do investigador, pois permite entender de forma adequada a natureza de um fenômeno social. (RICHARDSON, 1999).

A pesquisa de campo realizada tinha o intuito de diagnosticar o fenôme no do turismo está inserido no município para identificar os problemas e buscar soluções para o desenvolvimento do turismo sustentável

Segundo Richardson (1999 p.38), os estudos que empregam uma metodologia qualitativa descrevem a complexidade de determinado problema, analisar a 
interação de certas variáveis, compreender e classificar processos dinâmicos vividos por grupos sociais e contribuir no processo de mudança de determinado grupo entendendo suas particularidades de comportamentos.

Para Richardson (1999 p.91) as pesquisas qualitativas de campo exploram particularmente as técnicas de observação e entrevistas devido à propriedade com que estas penetram. A pesquisa qualitativa foi uma tentativa de uma compreensão detalhada dos significativos e características situacionais, apresentadas pelos entrevistados.

Por meio da pesquisa qualitativa o pesquisador toma uma postura imparcial que permite aos entrevistados expressar a própria definição da situação (RICHARDSON, 1999)

Durante a pesquisa de campo os entrevistados ficaram a vontade para expressar suas opiniões, críticas e sugestões a respeito do turismo no município, o que representa uma das vantagens em se aplicar a pesquisa qualitativa, pois possibilita ouvir as pessoas que convivem e trabalham com a atividade, mantendo-se uma postura imparcial por parte do entrevistador.

Por essa razão foi realizada a pesquisa de campo no município de Soure, com três representantes dos órgãos públicos e privados, que trabalham diretamente com a atividade turística no município: Dário Pedrosa o ex-Secretário de turismo do município vizinho, mas que está sempre evolvido e presente em reuniões que discutam acerca do turismo local; João Lima o presidente do fórum de turismo que desempenha um papel importante de articulador do turismo local; Maria Algina gestora de turismo do Sebrae atuou em projetos de capacitação e qualificação profissional e dos serviços prestados pelos empreendimentos locais e o empresário local. Essas pessoas relataram seus pontos de vista e o desempenho da atividade nos últimos anos, expressaram também suas opiniões sobre o que poderia ser melhorado, pois acreditam que o turismo pode sim, considerado uma alternativa de desenvolvimento sustentável local. 


\subsection{Instrumentos da coleta de dados}

O tipo de pesquisa aplicada in loco foi à entrevista com perguntas semi-estruturadas, capaz de explorar vários pontos, vez que a atividade turística envolve diversos setores da economia: social e ambiental. Visto que, através deste método é possível obter do entrevistado o que ele considera de mais relevante sobre os impasses e potencialidades da atividade turística local.

A técnica da entrevista semi-estruturada permite um contato mais estreito entre o entrevistador e o entrevistado. É indicada quando o entrevistador não deseja impor a sua visão sobre a realidade local, tornando-a mais flexível do que a entrevista estruturada, pois não apresenta rigidez (RICHARDSON, 1999).

\subsection{Coleta de dados}

A coleta de dados serve para orientar o pesquisador quanto às informações que pretende obter para responder a problemática da pesquisa (VERGARA, 2007)

A coleta de dados foi realizada pela própria autora, no município de Soure - PA. No período de 26 a 29 de janeiro de 2008, no período da manhã e da tarde, com o intuito de obter informações referentes as dificuldades e possibilidades de implantação de projetos turísticos sustentáveis como alternativa de desenvolvimento local.

\subsection{Limitações do Método}

Segundo Vergara (2007 p. 59), todo método tem possibilidades e limitações, mas ainda assim o justificam como o mais adequado aos propósitos da investigação.

A princípio o objetivo deste trabalho era entrevistar representantes de órgãos públicos e privados, assim como associações e Ong's que estivessem ligados ao turismo no município para gerar um estudo de prospecção da atual situação do turismo local.

Criou-se uma grande expectativa quanto às informações que poderiam ser obtidas, visto que, a autora conhecia o município. Assim acreditou-se que o acesso aos representantes seria mais fácil. 
No entanto, durante a pesquisa de campo ficou constatado que as ONG'S e associações ligadas diretamente ao setor turístico não existiam mais. E os únicos órgãos representativos eram o Fórum de Turismo do Marajó que desempenha a função de articulador e intermediário entre a Secretaria de turismo local e a Companhia Paraense de Turismo - PARATUR; o SEBRAE que realizou vários projetos durante cinco anos no município, dentre eles o Amazônia do Marajó encerrado no mês julho de 2007; o ex-secretário de turismo de Salvaterra que apesar de atuar no município vizinho direciona ações voltadas também para Soure visando a consolidação do destino integrado entre os dois municípios; e a secretaria de turismo, esporte e cultura do município, mas esta se negou a prestar informações a respeito do turismo local apesar de várias tentativas de contato e insistência.

Ainda assim, estes representantes não possuem muitas informações e nem dados estatísticos consistentes e confiáveis. As ações acabam acontecendo de forma amadora e sem profissionalismo. Com exceção do SEBRAE que realizou alguns projetos nos últimos anos e gerou informações, mas principalmente relacionados à capacitação dos empresários locais, os outros citados não possuem estudos e nem dados confiáveis a respeito do turismo no município.

O SEBRAE apesar de possuir as avaliações referentes ao último projeto não pode disponibilizar ao público, porque a falta de parcerias fez com que essas informações ficassem guardadas no arquivo do SEBRAE.

Desta forma, as pesquisas realizadas no município ficaram comprometidas pela falta de informações consistentes.

Contudo, no ano de 2007 a PARATUR realizou pesquisas de campo nos seis pólos turísticos do estado do Pará. Dentre eles foram coletados dados sobre o turismo no município de Soure com o intuito de identificar detalhes referentes à demanda turística que o município recebe atualmente. Estes dados foram utilizados como secundários para complementar a análise dos dados deste trabalho, pois se trata de informações confiáveis coletadas pelo órgão responsável pelo turismo no estado.

Mesmo com as várias dificuldades encontradas para a realização deste trabalho, relacionados à carência de dados sobre o turismo local, acredita-se haver alcançado os objetivos propostos. 


\section{APRESENTAÇÃO DOS DADOS}

\subsection{Dados primários}

Os dados primários referem-se às informações obtidas por meio de entrevistas semiestruturadas aplicadas durante a pesquisa de campo, na qual foram abordados variáveis sobre os aspectos econômicos, sociais, ambientais e de infra-estrutura local. Essas informações foram disponibilizadas pelos representantes do turismo no município apresentados a seguir:

a) João Lima Pinheiro Presidente do Fórum de Turismo do Marajó atua como articulador e intermediário entre a Secretaria de Turismo e a PARATUR, órgão responsável pelo turismo no estado do Pará e ainda é proprietário da Eco Pousada Paracauary localizada no município de Soure;

b) Dário Pedrosa é ex-secretário de turismo do município de Salvaterra, que faz fronteira com Soure. Atualmente é secretário de Educação em Salvaterra, mas ainda atua de maneira incisiva nas questões referentes ao desenvolvimento do turismo na região.

c) Maria Algina Soares Silva foi Gestora do departamento de Turismo no SEBRAE/PA atuou como coordenadora do Projeto Turismo Amazônia do Marajó durante três anos conhece bastante o município por ter trabalhado durante esses anos junto aos os empresários locais através de cursos voltados para a capacitação e profissionalização das pessoas que atuam diretamente com os turistas, além de ter atuado na elaboração de roteiros turísticos e guias para o município.

\subsection{Dados secundários}

Os dados a seguir referem-se à pesquisa realizada pela PARATUR no município de Soure nos períodos de alta estação (julho) e de baixa estação (novembro), para identificar detalhes da demanda turística que a ilha recebe atualmente. Está pesquisa serviu de base complementar à análise dos dados.

4.2.1 Perfil dos turistas que visitaram o município no ano de 2007:

a) Quanto ao Gênero: 
Na distribuição de turistas por sexo, 52,8\% dos visitantes são do sexo masculino e $46,2 \%$ são do sexo feminino.

b) Quanto à faixa etária a pesquisa demonstrou que a maior parte dos vistantes encontra-se na faixa etária de 35 a 50 anos com 43,4\% do total.

c) Tempo de permanência média dos visitantes no município é de 4,5 dias

d) Quanto à profissão:

Gráfico 1 - Profissão dos visitantes

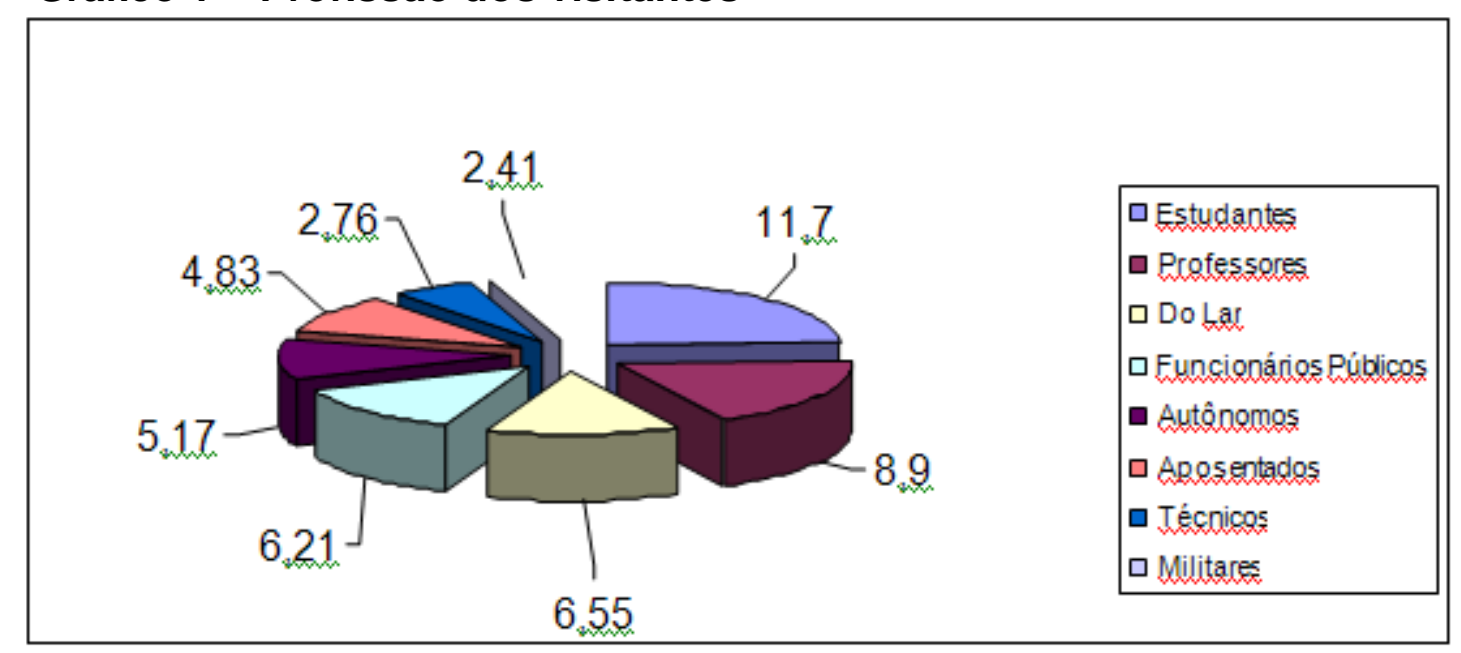

Fonte: PARATUR

O gráfico 1 demonstra um equilíbrio em relação a profissão dos visitantes, a maior porcentagem refere-se aos estudantes com $11,7 \%$, seguido de autônomos com $8,9 \%$, do lar com $6,55 \%$ e dos funcionários públicos com $6,21 \%$, considerados os mais significativos.

e) Situação econômica:

A Renda Bruta Mensal dos turistas que visitam o município de Soure concentra-se com maior freqüência no intervalo de $R \$ 2.400,00$ a $R \$ 4.800,00$. A participação destes turistas é de $42,8 \%$ do total de visitantes.

f) Principais estados emissores: 


\section{Gráfico 2 - Principais estados emissores}

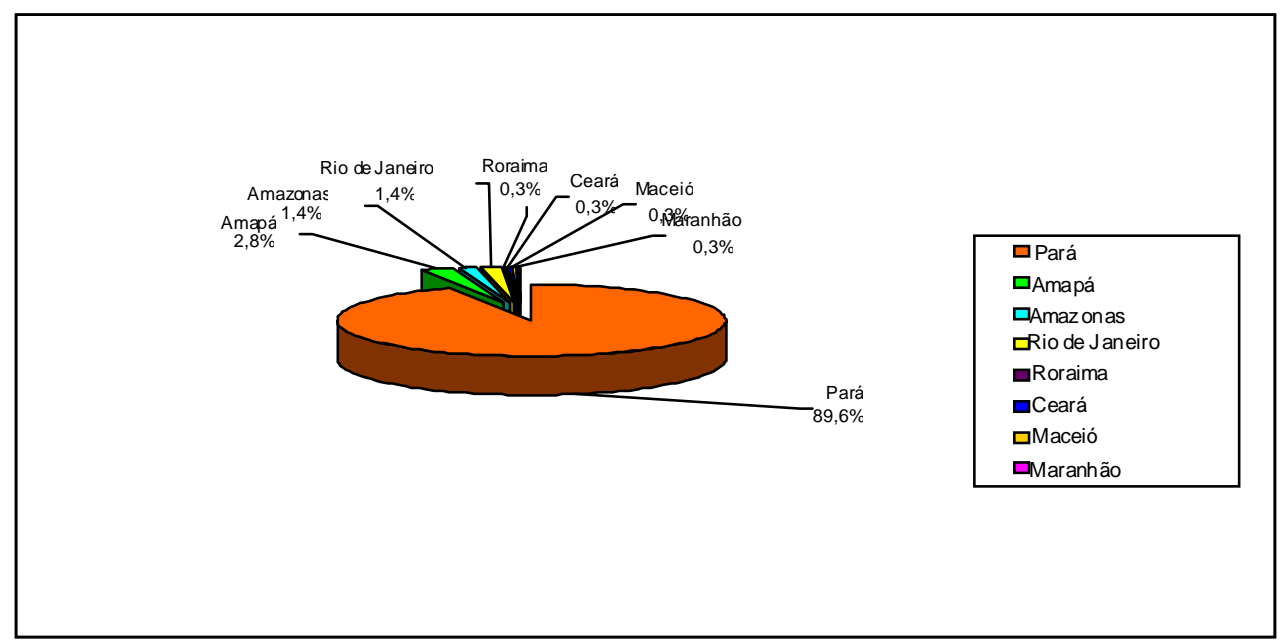

Fonte: PARATUR

De acordo com o gráfico 2, o Estado do Pará se destaca com uma participação de $89,6 \%$ deste mercado. Quanto aos outros estados, destacam-se o Amapá que contribui com 2,8\% da participação; o Amazonas contribui com 1,4\% da participação dos visitantes; Rio de Janeiro 1,4\%; Roraima 0,3\%\{ Ceará 0,3\%; Maceió 0,3\% e Maranhão $0,3 \%$. A partir dessas informações fica evidente o quanto é necessário investir em propaganda e promoção para o público paraense, principalmente em virtude da localização, o fato de estar próximo do município facilita a comercialização.

g) O principal motivo da visita ao município de Soure

\section{Gráfico 3 - Motivação}

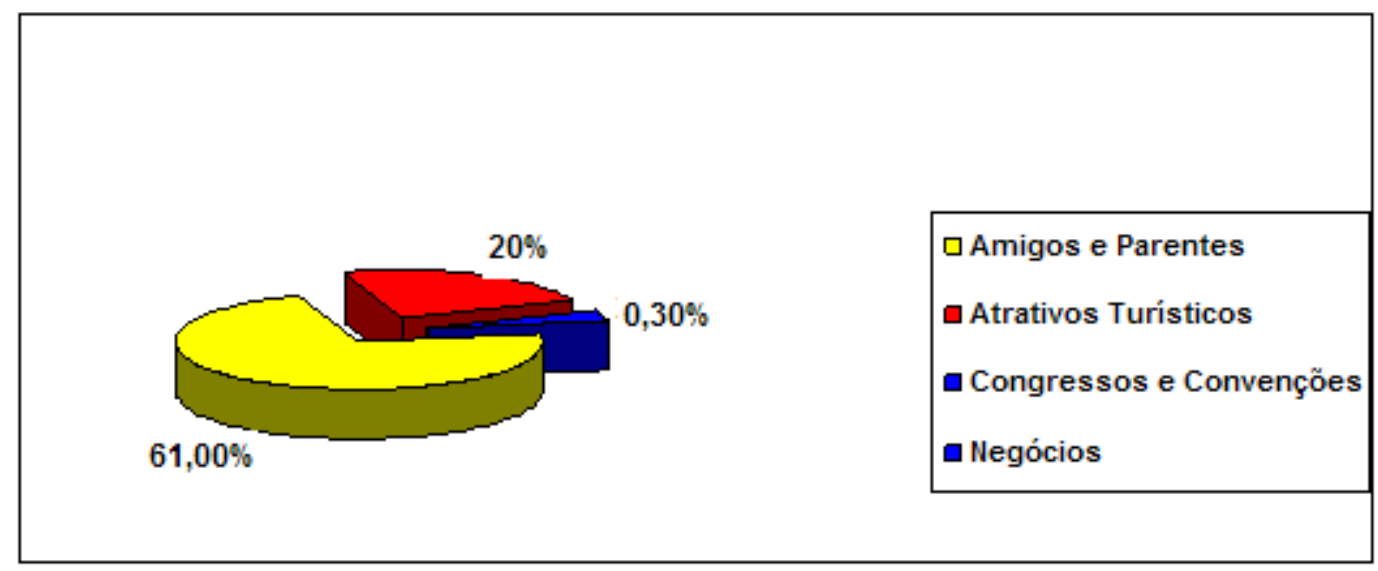

Fonte: PARATUR 
O gráfico 3 demonstra que $61 \%$ dos visitantes tem como motivação para chegar ao município visitar parentes e amigos, este fato pode estar relacionado a proximidade da capital e como foi demonstrado no gráfico 2 a maior porcentagem dos visitantes são do Pará. Em seguida os atrativos turísticos representam $20 \%$ do interesse dos turistas. Congressos e negócios representam $2,5 \%$ e 0,3\% respectivamente.

h) Atrativos turísticos que motivam os visitantes

\section{Gráfico 4 - Atrativos turísticos locais}

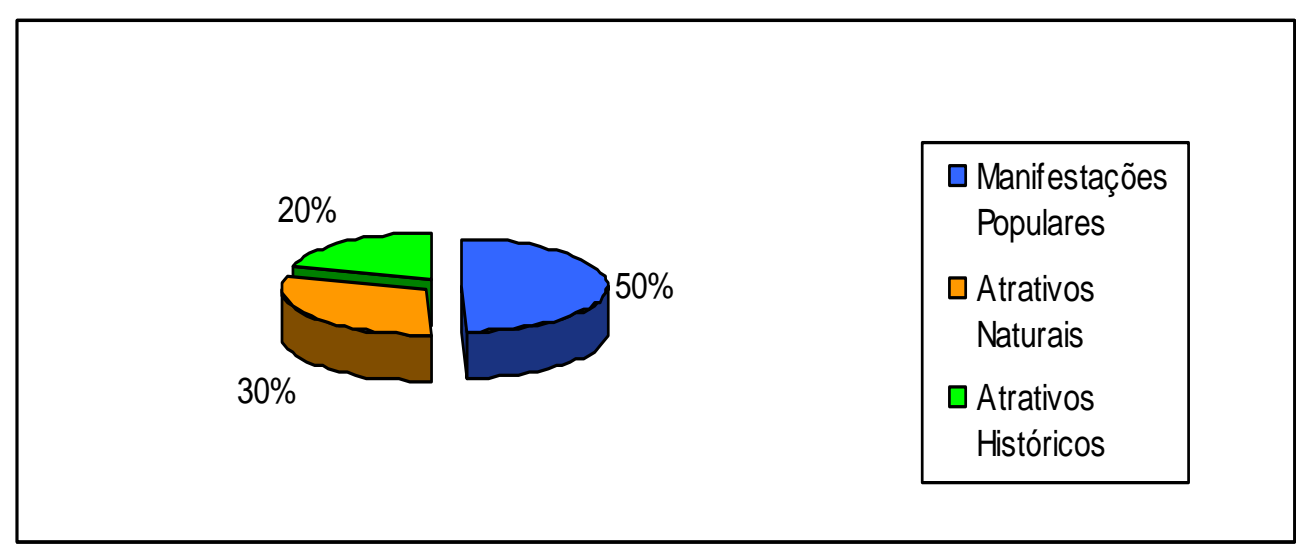

Fonte: PARATUR

O gráfico 4 refere-se aos atrativos turísticos locais mais procurados e com $50 \%$ está as manifestações populares, seguida dos atrativos naturais com $30 \%$ e os atrativos culturais com $20 \%$.

i) Os veículos de propaganda

\section{Gráfico 5 - Veículo de propaganda}

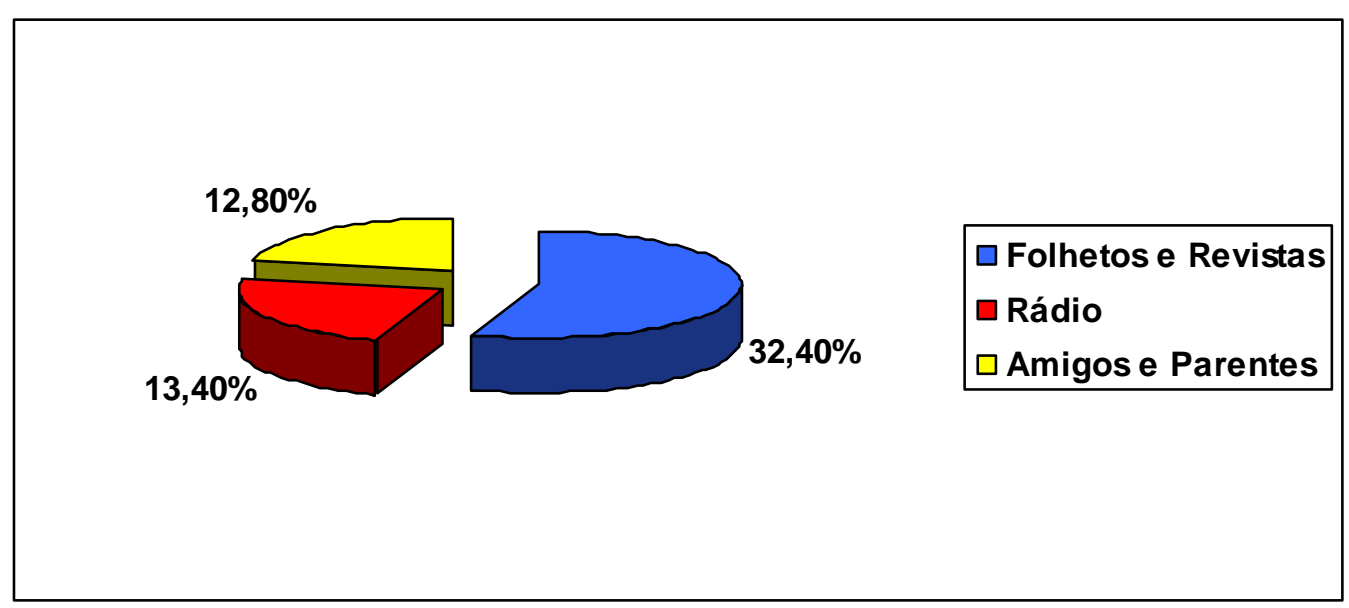

Fonte: PARATUR 
Os veículos de propaganda que mais influenciam os visitantes a conhecerem Soure são folhetos e revistas (32,4\%); rádio (13,4\%) e amigos e parentes $12,8 \%$.

j) Meios de hospedagem

\section{Gráfico 6 - Meios de hospedagem mais utilizados}

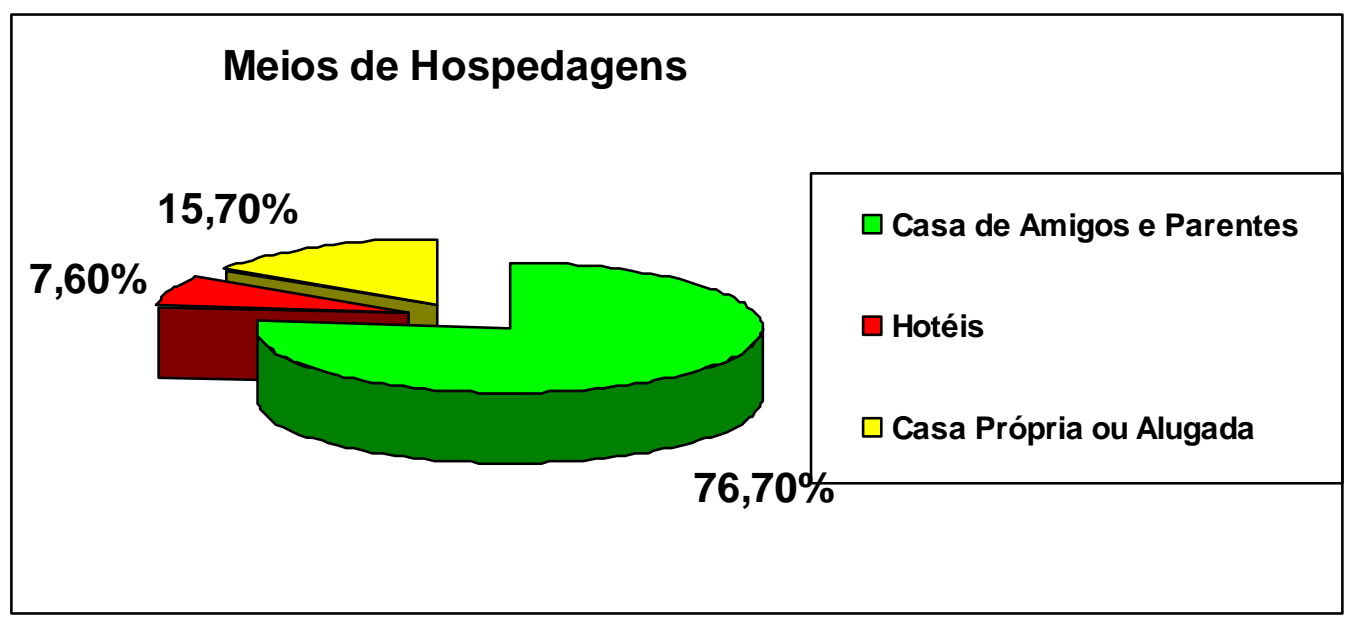

Fonte: PARATUR

Dos turistas que visitam Soure 75,2\% hospedam-se na casa de amigos e parentes; $6,2 \%$ hospedam-se em hotéis e 15,5\% ficam em casa própria ou alugada. Esses dados podem estar relacionados ao fato de que os principais visitantes são do estado do Pará. Baseado neles os empresários locais poderiam voltar suas ações para esse público que se encontra tão próximo e que poderia utilizar seus serviços.

I) Meios de transporte

\section{Gráfico 7 - Meios de transporte mais utilizados}

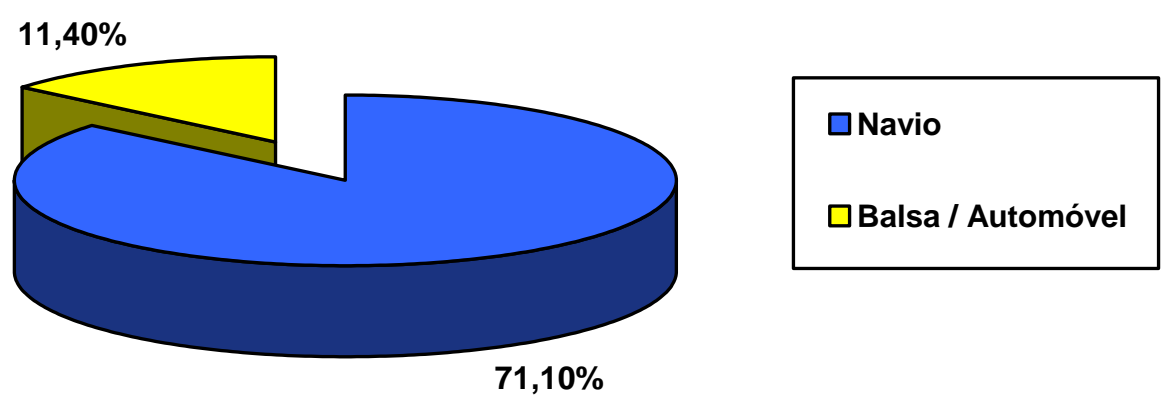


Fonte: PARATUR

A maioria dos visitantes $(71,1 \%)$ utiliza o meio de transporte navio para chegar a Soure e $11,4 \%$ viajam de balsa/automóvel. Isso pode estar relacionado à facilidade de acesso ao porto de Belém, localizado no centro da cidade.

m) Utilização do tempo livre

\section{Gráfico 8 - Utilização do tempo livre}

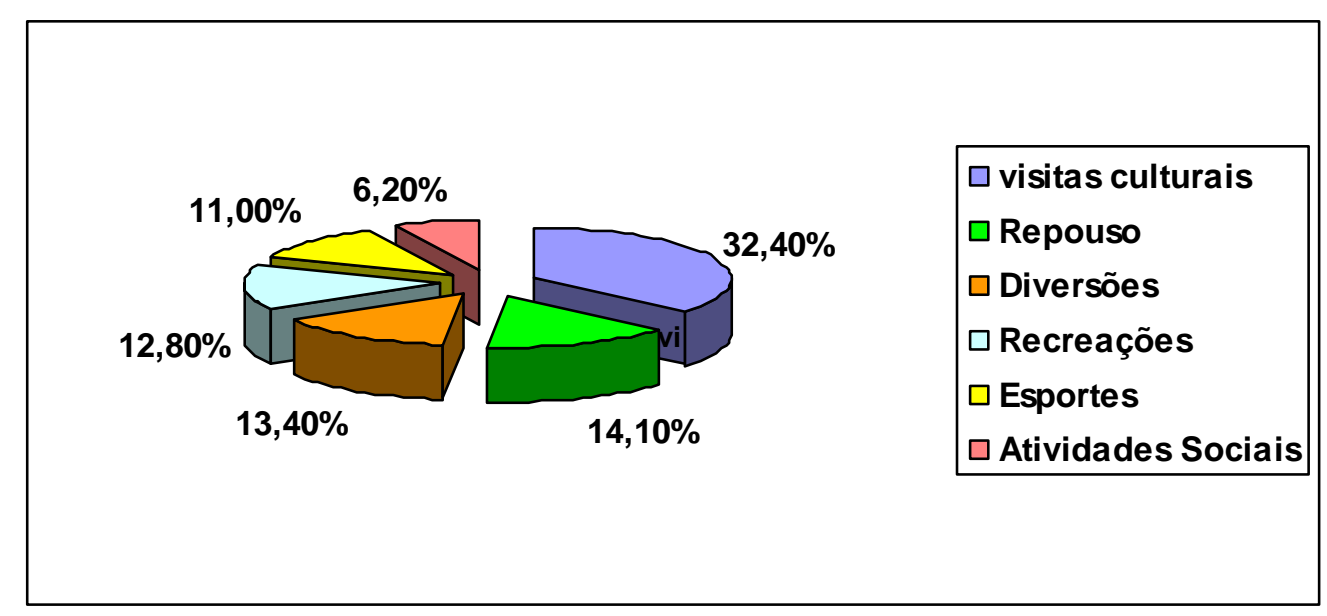

Fonte: PARATUR

Além de realizar negócios e visitar amigos e parentes os visitantes de Soure aproveitam o tempo livre em visitas culturais $(32,4 \%)$; repouso $(14,1 \%)$; diversões $(13,4 \%)$; recreações $(12,8 \%)$; esportes $(11,0 \%)$ e atividades sociais $(6,2 \%)$.

n) Característica do visitante

\section{Gráfico 9 - Caracterização do visitante}

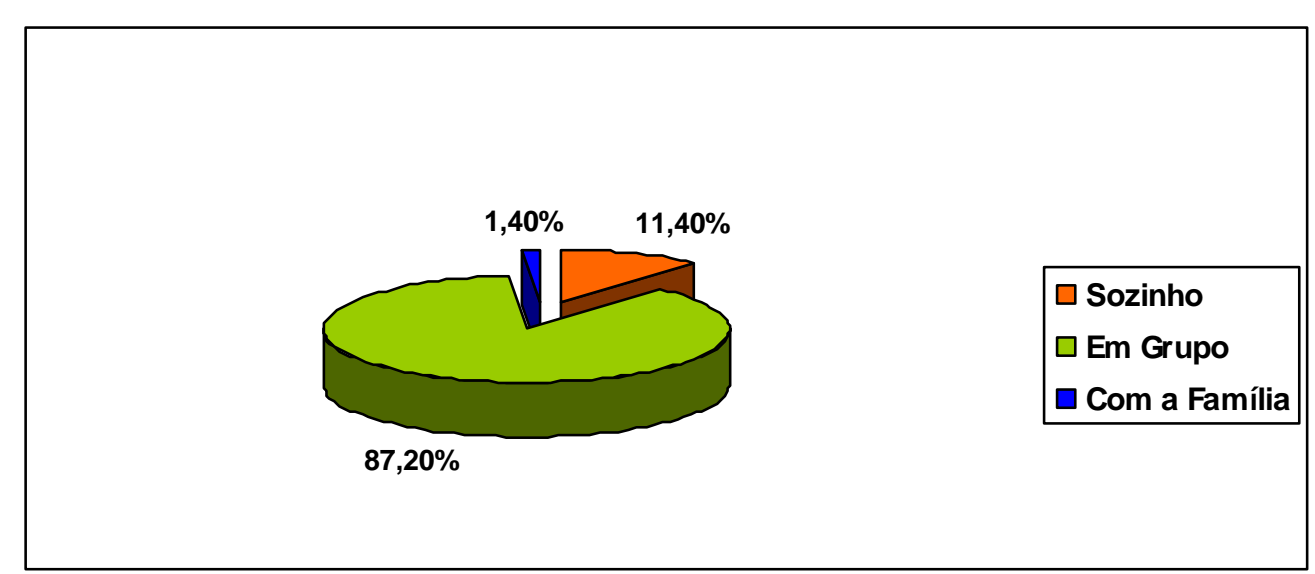

Fonte: PARATUR 
O gráfico 9 apresenta que o maior parte dos turistas `que visitam o município tem por característica viajar em $87,2 \%$ grupo, seguido dos que preferem viajar sozinho com $11,4 \%$ e $1,4 \%$ acompanhados pela família.

o) Despesa dos turistas

Gráfico 10 - Despesa média dos turistas (por dia)

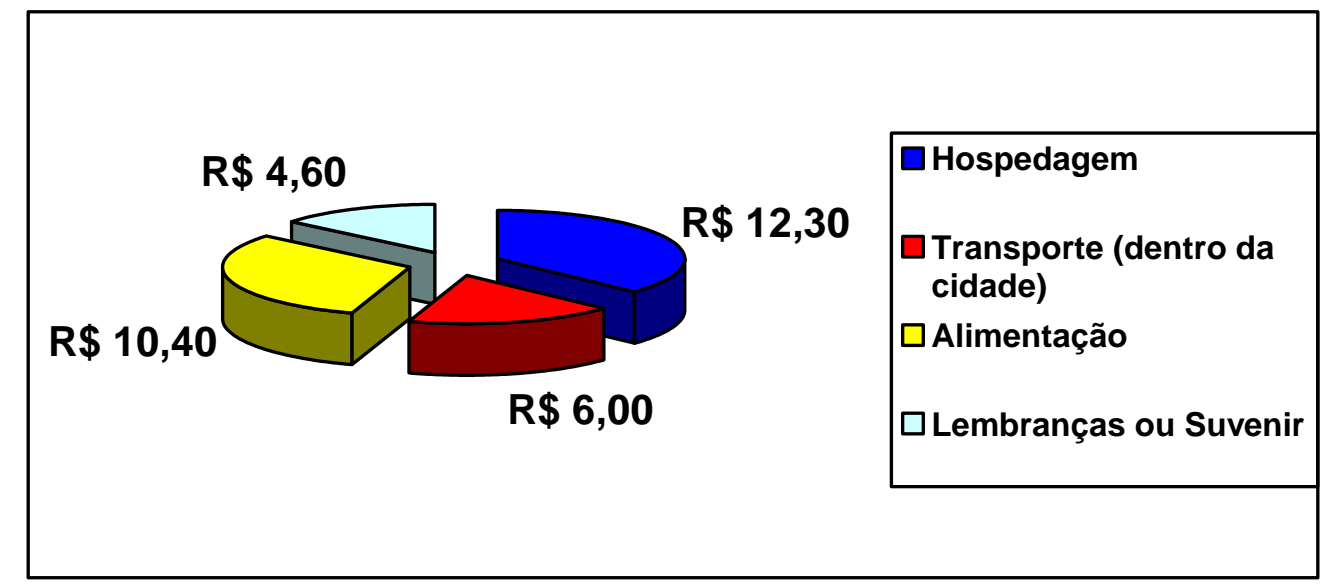

Fonte: PARATUR

O gráfico 10 demonstra que um visitante gasta em média por dia em Soure $R \$$ 33,30 , dividido em: hospedagem $\mathrm{R} \$ 12,30$; com transporte utilizado para deslocamento interno na cidade de Soure é de $R \$ 6,00$; com alimentação é de $R \$$ 10,40 e com lembranças ou suvenir é de $\mathrm{R} \$ 4,60$.

A partir desta apresentação de dados foi possível traçar o perfil dos turistas que visitaram o município durante o ano de 2007.

Predomina o número de turistas do gênero masculino, com $58,8 \%$. Na faixa etária de 35 a 50 anos, 43,4\%. Na maioria estudantes com $11,7 \%$ do total. Permanecem em média 4,5 dias no município. Apresenta uma renda no intervalo de $R \$ 2.400,00$ a $R \$$ 4.800,00. Com o maior número de procedência o estado do Pará, 89,6\%. O principal motivo da viagem é a visita a amigos e parentes com $61 \%$. Os atrativos que mais se destacam para os turistas são as manifestações culturais com $48,6 \%$. O veículo de propaganda que mais exerce influência aos visitantes são os folhetos e revistas $32,4 \%$. A maior parte dos turistas, $75,2 \%$ hospedam-se na casa de amigos e parentes. $71 \%$ utilizam o navio como meio de transporte para o município. Utilizam o 
tempo livre para visitas culturais $32,4 \%$. E por fim, a maioria costuma viajar em grupo e apresentam uma despesa mínima de $R \$ 33,30$ por dia.

A partir das informações geradas por essa pesquisa e do perfil traçado do turista que visitou a região, é possível iniciar um estudo sobre a demanda potencial e a demanda real do município, para então buscar elaborar planos de turismo sustentável. No entanto é necessário ressaltar que o levantamento mais detalhado do publico é imprescindível para um desenvolvimento turístico local satisfatório, pois só desta forma será possível planejar a atividade turística. 
Ainda referente à pesquisa realizada pela PARATUR foi elaborado o quadro 1 destacando os problemas mais acentuados que entravam à projeção do turismo no município. As informações contidas no quadro foram relatadas pelos turistas, que ainda contribuem com sugestões para contornar os problemas enfrentados pelo município.

Quadro 1. Fatores de impedimento para a projeção do turismo no marajó, mencionados pelos visitantes por ocasião de pesquisa de campo.

\begin{tabular}{l}
\hline IMPEDIMENTOS \\
\hline LIMPEZA \\
\hline A população não zela pela limpeza da cidade; tem mais sujeira na \\
praia do que no centro da cidade; lixos espalhados nas ruas e \\
nas praias; coleta de lixo deficiente; morosidade na limpeza \\
pública; carência de mão-de-obra na limpeza pública; falta de \\
lixeiras; as pessoas jogam lixo no chão; falta saneamento básico.
\end{tabular}

\section{TRANSPORTE}

- O transporte não é satisfatório; o meio de transporte é péssimo; as pessoas arrumam os seus pertences, preparam suas famílias, fazem um grande esforço para chegar na foz do rio, e não conseguem passagem para Belém, tem que retornar para a sede de cidade e com isso ficam insatisfeitos com a viagem e não querem retornar a ilha; Transporte interno caro e preço do transporte para Belém; os ônibus só fazem linha na hora que o barco chega na foz, em outros oportunidades os turistas ficam impossibilitados de visitar outras municípios; deveria ter mais transporte marítimos e terrestres, falta organização no transporte; as pessoas não sabem o horário dos ônibus, quando chegam no porto não tem informação a respeito do local de venda de passagem, onde estacionar o carro e etc...; falta sinalização

- No trânsito da cidade e na estrada; o transporte e a venda de passagens são deficientes; faltam barcos e condução; falta melhorar a estrada; deveria ter mais investimento em transportes fluviais; realmente o transporte é precário; falta aproveitar outras alternativas de transporte; não tem sinalização no trânsito.

ARTESANATO

- Os turistas que se hospedam em hotéis têm acesso ao artesanato por um preço muito alto; tem que ter mais lojas de artesanato; explorar mais o artesanato;

- Falta de cerâmicas/objetos produzidos com este material; não foi possível ver a produção artesanal da cidade; o pouco que se produz precisa ser mais original.

SEGURANÇA

- Deveria haver mais policiais nas ruas; falta segurança nas programações noturnas; percebe-se a presença do policiamento somente nos finais de semana; garantir infra-estrutura para os policiais (transporte, hospedagem, alimentação); muitas confusões nas praias.
SUGESTŐES

Campanha de educação ambiental

- Distribuição de um kit contendo orientação do tipo "mantenha nossa cidade limpa", no desembarque do visitante.

- Deveriam vender passagens em pontos de venda locados na cidade de Soure.

- Incentivar os empresários a investir em transportes alternativos aproveitando as particularidades da ilha, como carriolas puxadas por búfalos e etc...

- Revezamento das empresas para manter a linha permanente.

- Fazer travessia das pessoas Soure Salvaterra, com saída da frente da praça de Salvaterra.

- Dispor de pessoal para orientar os turistas (foz do rio).

Fonte: Companhia Paraens e de Turismo - PARATUR 
O quadro 1 representa a opinião dos visitantes em relação ao turismo no local, as autoridades municipais poderiam levar essas informações em consideração a fim de, melhorar e desenvolver a atividade turística no município. 


\section{ANÁLISE DOS DADOS}

O município de Soure apresenta um grande potencial no que diz respeito aos atrativos naturais e culturais presentes em seu território. Entretanto, a dificuldade de acesso principalmente em decorrência dos transportes e a pouca infra-estrutura existente no município colaboram para que a atividade turística não consiga obter êxito nos projetos voltados para o desenvolvimento turístico local.

O objetivo geral deste trabalho era realizar um estudo de prospecção da situação atual do município visando à implementação de projetos de turismo sustentável em relação à atividade turística, a partir da análise dos aspectos econômicos, sociais, ambientais e a infra-estrutura local, bem como identificar os impactos negativos e positivos, além de gerar subsídios para a elaboração de futuros planos direcionados ao turismo local para os órgãos do poder público e privado interessados em investir no município e propor o turismo sustentável como uma alternativa de desenvolvimento local.

Em seguida, serão relatados os principais aspectos abordados nas entrevistas com os representantes do turismo local:

\subsection{Aspectos relacionados à Infra-estrutura}

A infra-estrutura foi um dos principais pontos abordados e destacados pelos entrevistados, para eles as condições precárias dos meios de transportes utilizados para chegar ao município de Soure e a falta de qualidade dos serviços oferecidos pelos estabelecimentos que recebem a demanda, são fatores que comprometem o desempenho da atividade turística local.

O Presidente do Fórum de Turismo João Lima afirma "que não se pode oferecer um turismo com uma estrutura razoável". Para ele "o governo anterior ao vigente realizou ações importantes para o desenvolvimento da atividade no estado do Pará. No entanto, esqueceu de criar uma estrutura de transporte, apesar de algumas ações voltadas para a melhoria nas estradas que dão acesso ao município. Em contra partida, os transportes que fazem a travessia do porto de Belém ao porto de Camará até finalmente chegar a Soure encontram-se em condições precárias. E não é só a questão do transporte fluvial, mas também o rodoviário dentro da llha". 
João acrescenta ainda, "que no caso específico do Marajó a condição do transporte é um grande problema para o crescimento do turismo no munic ípio".

O município carece de investimentos no setor de transporte, caso contrário, se torna difícil investir em um local que não oferece condições de acesso seguro e com o mínimo de conforto e qualidade. De acordo com o que foi proposto no referencial teórico quando as cidades do nordeste começaram a desenvolver turisticamente os governos locais investiram maciçamente nos meios de acesso ao destino e na infraestrutura de apoio ao turismo local.

Estas informações poderiam ser utilizadas e estudadas pelos representantes do poder público municipal e estadual, com o intuito de solucionar os problemas referentes ao transporte para o município. Ações desse tipo não beneficiariam apenas os turistas, mas principalmente os residentes que necessitam e utilizam constantemente os meios de transporte.

Os dados obtidos pela PARATUR revelaram a insatisfação dos turistas em relação ao transporte que consideram péssima qualidade e os preços elevados. No entanto, como não existe outra forma de se chegar ao município os visitantes continuam utilizando os barcos $(71,1 \%)$ e balsas $(11,4 \%)$ para se deslocar. $O$ transporte aéreo não foi nem mencionado, por ser muito caro.

Segundo Veloso (2003), a infra-estrutura existente no município é um aspecto da potencialidade turística. São consideradas as condições viárias, os aspectos urbanos com relação à segurança, limpeza, meio ambiente, saúde entre outros.

João Lima acredita na evolução do turismo no Marajó "desde que sejam tomadas medidas direcionadas para município, o que está faltando na realidade são medidas políticas".

João acrescenta que "o governo deve criar condições para que o turismo no Marajó se desenvolva, enquanto isso não for feito a coisa realmente não vai acontecer".

Nos dados obtidos pela PARATUR destacam-se as sugestões dadas pelos turistas para a solução do transporte no município entre elas: oferecer incentivos aos empresários para que eles possam investir na criação de transportes alternativos, aproveitando as particularidades. 
Para João Lima "apesar dos problemas de transporte, a infra-estrutura hoteleira é boa, poucos municípios do estado do Pará têm a estrutura hoteleira que tem em Soure, muita coisa tem que não é legal, mas tem outras coisas que estão boas”.

Maria Algina Gestora do departamento de Turismo do SEBRAE considera que "o transporte deixa muito a desejar, já passei por problemas voltando de soure a trabalho, o barco ficou por alguns minutos a deriva no meio da baía, fiz denúncias, mas não aconteceu nada, as coisas não mudam, não há interesse em melhorar o turismo para o local".

Além do transporte, os meios de hospedagem representam outro grande problema para a região. Segundo Dário ex-secretário de turismo de Salvaterra "a informalidade dos estabelecimentos prejudica o turismo na região, a maioria dos hotéis e restaurantes não possuem pessoas jurídica constituída o que os impede de participar de programas de incentivo ao turismo regional". Dário ainda acrescenta que "a resistência em regulamentar o estabelecimento é devido aos impostos que eles terão que pagar"

$\mathrm{Na}$ pesquisa de campo foi constatado que a viagem de Belém até o município de Soure é cansativa dura em média $4 \mathrm{~h}$, utiliza-se três meios de transportes diferentes durante o percurso, e ao chegar ao município para quem atravessa de balsa não tem nenhuma sinalização e nem um porto que possa servir de apoio e de informação para o turista.

Outro ponto a ser destacado durante a pesquisa de campo foi à carência de transportes dentro da ilha, só existem moto-táxi e táxi e um único ônibus, que vai do centro da cidade a praia do pesqueiro, $13 \mathrm{~km}$ do centro urbano. Este fato limita muito o turista que não conhece o município.

As informações relatadas acima comprovam a necessidade que o município apresenta em relação sua infra-estrutura. No entanto é citado muito mais os aspectos de transporte do que os outros que também fazem parte da infra-estrutura: como as estradas, o abastecimento de luz e água. Entende-se que para os representantes entrevistados o transporte é a questão principal de impedimento para o turismo no município, mas, vale ressaltar que o fato de melhorá-los, não pode ser considerado suficiente para a implantação de projetos turísticos sustentáveis, pode 
ser sim, um dos problemas a serem resolvidos mais não o único relacionado à infraestrutura local.

\subsection{Aspectos sociais}

O turismo quando inserido no meio social é capaz de provocar algumas transformações no modo e na qualidade de vida dos residentes.

As entrevistas revelaram que depois da criação do Ministério do turismo, surgiu à necessidade de criar novos produtos turísticos para serem apresentados no Salão de Turismo, a partir de então projetos começaram a ser desenvolvidos, com o intuito de elaborar roteiros turísticos no município.

Para João, "no ano 2000, o SEBRAE e a PARATUR foram os indutores do aumento de pousadas no marajó, criou-se uma grande expectativa em cima do crescimento do turismo no município. Disseram que o turismo ia deslanchar, e as pessoas que tinham terrenos começaram a investir na construção de pousadas, mas na realidade a demanda não aumentou e ainda foi toda fragmentada".

João destaca ainda que a taxa de ocupação nos ano de 2005 e 2006 variava entre 40\%a 65\% e que em 2007 essa variação caiu para 10\% a 25\%.

No entanto é preciso ressaltar que esta prospecção não foi baseada em nenhum dado estatístico confiável, ele fez uma dedução própria de acordo com o fluxo turístico e a quantidade de ônibus turísticos presentes na cidade nos anos de 2005 a 2006 comparando-os a 2007. Entretanto a informação é pertinente, visto que, ele como empresário do setor de hospedagem trabalha direto com a recepção de turistas e pacotes turísticos e conhece os períodos mais procurados pelos turistas.

Maria Algina através do Projeto Amazônia do Marajó procurou realizar ações com a comunidade voltadas para a disseminação da cultura em empreendedora no município, através de capacitação, com orientações especificas para o mercado turístico, priorizando a qualidade no atendimento, a melhoria dos equipamentos e serviços, transporte, hospedagem e alimentação.

E acrescenta ainda que "o projeto foi todo pautado com a participação dos atores locais, através de encontros com os empresários, focando um planejamento voltado para o desenvolvimento sus tentável da atividade turística". 
Ações como estas são importantes para formar pessoas qualificadas para trabalhar com a atividade turística, além de que contribui socialmente para a inclusão no mercado de trabalho.

Entretanto Maria Algina destaca que "o grande problema para o desenvolvimento do turismo no Marajó é a grande resistência por parte dos proprietários dos estabelecimentos em melhorar os serviços oferecidos no município. Desde 2003 são realizados projetos com parceria do SEBRAE no sentido de estimular novos empreendimentos e de melhorar a qualidade dos já existentes, mas pouca coisa mudou nesse período (2003 - 2007), os resultados não apareceram e isso comprometeu a credibilidade de investir no município".

Infelizmente este é um fato muito comum na região, o que acaba sendo prejudicial, pois outros órgãos ou entidades acabam não investindo mais por falta de estudos que comprovem a viabilidade ou mesmo a falta de avaliação sobre os projetos que já ocorreram.

Outro fator relevante destacado por Maria Algina diz respeito à visão equivocada por parte dos empresários locais que "apresentam uma grande resistência em entender que o turista de Belém é que vai sustentar o turismo no município, mas eles preferem os turistas estrangeiros, por isso cobram preços mais altos e ainda dizem que o turista de Belém é muito exigente. Mas o exigente que eles se referem é pelo fato de que os belenenses conhecem a região e não admitem ser enganados, pagando preços altos e recebendo serviços de baixa qualidade. O turismo no Marajó, esta sendo um trabalho muito difícil".

Os empresários locais ainda não entenderam que sai muito mais caro investir no turista de outro estado, sendo que existe um mercado em potencial que é a Capital do estado Belém. Além do mais, eles não têm uma associação que possa ajudá-los na comercialização de seus produtos, ou mesmo na formação de produtos interligados.

Segundo Maria Algina "são poucas as agências que comercializam o produto Marajó, e além do mais os empresários de Soure não gostam de ter seus serviços de hospedagem vendidos pelas agências, porque elas cobram uma taxa de serviço que eles não querem pagar, preferem divulgar a seu modo, mas desse jeito fica quase impossível o turismo se desenvolver". 
Isso dificulta o turismo local e a criação de representantes e associações fortes e atuantes, para fortalecer o turismo e criar produtos competitivos, capazes de atrair mais visitantes.

Maria Algina acrescenta que "o turismo na cidade de Soure já teve seu grande momento, quando foi criado o ministério do turismo e o programa de roteirização. Antigamente quando se fazia viagem para Soure era possível encontrar muitos turistas, hoje em dia é raro, a maioria das pessoas que vão pra Soure são os moradores de lá, que estavam em Belém ou profissionais que vão a trabalho."

De certa forma, isso pode ser confirmado através dos dados obtidos pela PARATUR, o qual revela que o principal motivo da visita ao município de Soure é a visita a amigos e parentes com $61 \%$. Tanto que, $75,2 \%$ dos visitantes ficam hospedados na casa de amigos e parentes. E geralmente é formado por grupos, que correspondem a $87,2 \%$ dos visitantes e isso pode ser associado a outro dado da pesquisa que os estudantes detêm o maior percentual com 11,7.

Estes números confirmam que os empresários tendem a continuar perdendo se não procurarem se unir para desenvolver o turismo na região. De acordo com a pesquisa da PARATUR mais de $50 \%$ dos visitantes vão para casa de amigos ou parentes, comprometendo o desempenho dos empresários locais que poderiam conquistar esses potencias clientes.

A questão dos atrativos é outro ponto abordado por Maria Algina, "durante o projeto Amazônia do Marajó foram criados e formatados circuitos integrados dentro dos municípios de Soure e Salvaterra. O objetivo do projeto era indicar sugestões de passeios a serem realizados nos município evidenciando os atrativos naturais e culturais e ainda possibilitando a geração de empregos para a população local que ficaria responsável pela execução dos passeios".

No entanto, não se tem dados referentes à avaliação desses roteiros, nem informações se ainda estão sendo implementados pela população local, devido à falta de conclusão do projeto, que foi encerrado em 2007 e por falta de parcerias não fez as avaliações.

Contudo, a iniciativa de criar roteiros integrados é uma maneira de inserir a população residente na atividade turística, beneficiando o social, o econômico e o 
ambiental, já que os roteiros são previamente estudados e avaliados quanto à viabilidade.

Mas, as avaliações finais são importantes para a elaboração de projetos sustentáveis no município, pois a partir delas é possível identificar os impactos negativos e positivos gerados pela atividade turística, e a maneira como proceder para diminuir os impactos sociais advindo do aumento do fluxo de turistas, inserção de novas culturas trazidas pelos turistas. Antes de tudo é preciso prezar pela qualidade de vida dos residentes.

\subsection{Aspectos Econômicos}

Através das pesquisas realizadas no município foi constatado que a economia local está baseada no setor primário, sem muitas oportunidades de empregos para os residentes.

De acordo com João, os aspectos econômicos do município baseiam-se na pecuária e na pesca artesanal. Entretanto, "essas duas atividades estão numa situação de estanque [sic], não evoluíram e não vão evoluir mais, do que já foram no passado".

"Além do mais os grandes pecuaristas da região possuem hoje a mesma estrutura daquela época, e isso não elevou o número de emprego no município. A perspectiva de emprego hoje na região é o turismo", acrescenta João Lima.

Para ele a atividade turística seria a solução para o Marajó, porque "o turismo é a atividade que mais gera renda, sem dúvida".

Mas, Veloso (2003) alerta que o turismo não deve ser tratado como uma "mina de ouro", mas sim, como uma fonte inesgotável de satisfação humana, para que a comunidade possa conviver com a atividade turística e participar dos seus reais benefícios.

Até porque o turismo não irá solucionar todos os problemas locais, muito pelo contrário o aumento exacerbado do fluxo turístico sem planejamento comprometerá a qualidade de vida local, gerando ainda mais problemas.

Mas, para João "a atividade turística é que mais distribui renda, porque eu tenho funcionários, se eu tiver uma demanda muito grande vou ter que colocar gente pra 
ajudar. Vou utilizar os passeios pras fazendas, pras praias, lá eles consomem, quer dizer [sic] pulveriza".

De certa forma isso está correto, desde que a população local em sua maioria seja beneficiada. A realidade em Soure é diferente, visto que os hotéis e pousadas de médio porte concentram os benefícios em seu poder. Pois, estes empreendimentos têm seus meios de transporte próprio, realizam suas vendas através de pacotes fechados diretamente com o estabelecimento e oferecem aos seus hospedes serviços e até manifestações culturais de forma que o turista passe o dia dentro do hotel, ou seja, a população residente fica excluída.

Dário afirma que "os estabelecimentos são gerenciados e formados por equipes de serviços ligados a família do proprietário para diminuir as despesas e reter entre as famílias o máximo dos lucros com o negócio".

Isso comprova como o turismo ainda é praticado de forma amadora. Tanto que Dário destaca a "informalidade dos empreendimentos turísticos na região é um fator relevante porque prejudica o crescimento econômico da atividade no município".

Segundo Veloso (2003) "os municípios de grande potencial turístico acabam ficando a margem da sua verdadeira capacidade, por falta de capacitação e profissionalização que muitas vezes são baratos, mas não produzem um resultado satisfatório para os hóspedes".

E esses fatores ainda contribuem para a não geração de emprego para a população local.

Outra questão levantada durante a pesquisa por Maria Algina, foi a dificuldade encontrada durante o projeto Amazônia do marajó, onde os empresários locais se apresentam resistentes em entender que o turista em potencial é o da capital Belém "é o turista de Belém que vai sustentar o turismo no município, mas eles preferem os turistas estrangeiros, porque pagam com moeda estrangeira e, aceita, na opinião deles os preços altos cobrados pelos serviços ao contrário dos paraenses".

No entanto, João que também é empresário local tem uma visão diferente a respeito deste assunto, para ele "o marajó tem um mercado próximo chamado Belém, e no momento que esse mercado começar a se voltar pra lá, nós teremos uma demanda natural, não vou precisar vender meu produto em outros estados e acredito que o 
máximo que levaríamos para ganhar esse, mercado seriam seis meses, eu vejo isso como uma boa perspectiva para o turismo no município".

Essas informações podem ser comprovadas através dos dados obtidos pela Companhia Paraense de Turismo - PARATUR, no qual confirma que o principal mercado emissor para o município de Soure é o estado do Pará com 89,6\%.

Isso reforça o que foi citado por Maria Algina e João Lima, anteriormente o público belenense é que vai sustentar a atividade turística no município e não apenas os estrangeiros. E também pode representar uma alternativa para a geração de emprego local, utilizando a mão-de-obra do município, em vista de melhorar a qualidade de vida dos residentes.

\subsection{Aspectos ambientais}

Dentro dos aspectos ambientais foi destacado pelos entrevistados o grande potencial turístico do município para o desenvolvimento do ecoturismo, turismo de aventura, arqueológico, devido os atrativos turísticos ligados a natureza, sítios arqueológico e os atrativos culturais. A cidade de Soure detém uma boa parte de recursos naturais do arquipélago.

Um aspecto positivo destacado por Dário Pedrosa é que "o município possui vários atrativos que podem ser utilizados na atividade turística de forma, sustentável, responsável e profissional como: visitas as comunidades quilombolas presentes na região, à prática da pesca esportiva, o turismo de aventura, as trilhas ecológicas". Dário acrescenta ainda que "é necessário dinamizar o produto Marajó no contexto da oferta de opções para que o visitante possa melhor aproveitar seu tempo aqui, além de envolver mais pessoas na oferta destes serviços e adereços do produto".

Maria Algina cita a necessidade de elaborar roteiros turísticos na região, e através do programa Amazônia Marajó foram desenvolvidos roteiros integrados entre os municípios de Soure e Salvaterra, utilizando os recursos naturais existe ntes nos dois municípios, mas sempre preocupados com a preservação desses recursos.

As praias, mangues e as regiões dos campos alagados de acordo com Maria Algina "foram inseridos como roteiros turísticos elaborados e desenvolvidos com a comunidade local, no entanto, devido estudos mais aprofundados, verificou-se que 
seria inviável passeio através de trilhas próximo aos mangues, por causa do alto impacto que iria causar aquele meio ambiente".

Para João "o município tem uma estrutura de natureza que pode ser perfeitamente utilizada para a atividade turística, não resta a menor dúvida, tem praias, o produto turístico do marajó é a praia fluvio - marítima. Soure é um dos poucos lugares do mundo que tem praia com água doce e salgada".

João acrescenta ainda que: "no nosso caso, isto é, o meio ambiente local, o turismo se beneficia a medida em que ele é aproveitado (não gosto da expressão explorado) de maneira consciente, sem agressão, sem que seja transformado em turismo de massa. O turismo prejudica o meio ambiente (todos), quando se faz de forma inversa, ou seja, massificando-o, e utilizando-o de forma irracional. Eu finalizo te dizendo que o nosso meio ambiente não é para ser pisado, mas sim, contemplado".

Soure apresenta um grande potencial turístico natural voltado para a natureza como foi destacado pelos entrevistados. Entretanto seus recursos ainda não estão sendo aproveitados de maneira correta e sustentável, o desaparecimento dos sítios arqueológicos existentes na região é uma confirmação disto. Além dos aspectos econômicos, sociais e de infra-estrutura o ambiental tem sua relevada importância. 


\section{CONSIDERAÇÕES FINAIS}

O estudo prospectivo realizado no município de Soure ressalta que a atual situação do município, considera desfavorável a implantação de projetos turísticos no local, a menos que sejam priorizados investimentos na infra-estrutura de acesso e de apoio ao turismo no município.

Verificou-se que em nenhum momento foram realizados estudos para detectar os problemas que impedem o desenvolvimento do turismo no município, existem apenas grupos isolados mas, que não se unem para difundir e desenvolver a atividade.

Os resultados pretendidos pelos objetivos específicos foram parcialmente alcançados, após a análise dos aspectos econômicos, sociais, ambientais e infraestrutura, bem como na identificação dos aspectos positivos e negativos que o turismo poderá proporcionar à região.

Esta pesquisa é de fundamental importância para o desenvolvimento de ações futuras, pois evidencia a problemática da atividade turística enfrentada pelo município de Soure (PA). É um estudo que gera subsídios e informações preliminares, para que os órgãos do governo e da iniciativa privada possam basearse para a elaboração de futuros projetos turísticos.

O estudo prospectivo demonstrou por meio das informações obtidas nas entrevistas e dos dados coletados pela PARATUR que para a implantação e êxito de projetos turísticos sustentáveis em Soure é necessário procurar sensibilizar os representantes do poder público municipal sobre a importância do turismo e mostrálos a possível contribuição do mesmo para a dinamização da economia local, hoje baseada no setor primário (pesca agricultura e pecuária). Além disso, despertar nos empresários o interesse em investir no município. Para desta forma, propor o turismo sustentável como uma alternativa de desenvolvimento local.

Outro ponto a ser destacado refere-se aos meios de transporte que representam um dos principais problemas enfrentados pelo município. Investimento no setor de transporte hidroviário pode ser visto, como agente indutor no aumento do fluxo turístico para o local. Nesse sentido, torna-se imprescindível a atuação do poder público municipal para o sucesso da atividade turística na cidade de Soure. 
Cabe ainda, em outra análise, ouvir a voz do núcleo receptor quanto ao interesse em participar de um sistema de transporte alternativo turístico, que facilite 0 deslocamento tanto do turista quanto dos residentes com intuito de movimentar a economia local.

Os investimentos em infra-estrutura não irão beneficiar apenas os turistas mas, principalmente a população residente que poderá contar com meios de transporte e serviços (segurança, saúde, abastecimento, educação, entre outros) de qualidade. Estes fatores podem ser considerados ações básicas mas, a falta delas compromete o desempenho da atividade turística no município.

Além disso, falta de informação e qualificação por parte dos empresários locais ligados a atividade turística pode ser considerado outro fator em questão que deve ser reavaliado.

Os empreendimentos que estão preocupados apenas com o lucro a curto prazo e não priorizam investimentos em seus estabelecimentos e no quadro de funcionários não conseguem se manter no mercado por muito tempo e ainda dispõe de serviços insatisfatórios. Atitudes desse tipo impedem que as receitas geradas pelo turismo beneficiem a maior parte da população, e isso acarreta sérios impactos sociais e econômicos, como a concentração de renda e a exclusão social.

Outro ponto destacado pelo estudo em relação aos empresários locais refere-se a qualificação de seus colaboradores e dos serviços prestados. Quebrando paradigmas de que o melhor turista é o estrangeiro, na verdade todos os turistas são importantes, não importa seu local de origem todos merecem respeito e qualidade. Hoje, os turistas em potenciais para o município de Soure são os da capital do estado, Belém, pela proximidade e por ser o ponto de partida para os que desejam conhecer a llha do Marajó.

Este estudo prospectivo mostra ainda que ações desenvolvidas a partir do turismo sustentável poderiam contribuir para o crescimento das atividades pecuaristas e de pesca no município, já que, os estabelecimentos hoteleiros e os restaurantes necessitam comprar carne e peixes para servir nos seus estabelecimentos. Desta forma, estaria contribuindo para a geração de emprego e renda para a população local. E até poderia proporcionar ao município a voltar ao patamar de exportador de gado e pesca, como em décadas passadas. 
Os dados mostraram que a maior parte do ano a cidade fica ociosa, sem perspectiva de emprego para a população que acaba migrando para a capital do estado em busca de trabalho. Com o planejamento do turismo e a retomada das atividades pecuárias e de pesca, esta situação poderia ser contornada.

O município de Soure apresenta características que se enquadram no novo perfil dos turistas, que estão em busca de novas experiências, principalmente as voltadas para o contato com a natureza. Só precisa estruturar melhor a cadeia produtiva e a infra-estrutura, para atrair o novo perfil dos turistas diferenciado, culto, exigente e que esta em busca de vivências e experiências, no qual possa levar consigo lembranças do lugar visitado.

É fundamental enfatizar que a partir do momento que o governo trabalhar em parceria com o privado realizando ações em prol do desenvolvimento da atividade turística no município e elaborar projetos de turismo sustentável, Soure poderá se considerar de fato um município preparado para desenvolver a atividade turística deixando de ser apenas um potencial para transformar-se em um destino turístico consolidado e competitivo no cenário brasileiro.

Este trabalho evidencia que na realidade o que se vê é a falta de vontade política das autoridades municipais em fazer com que o turismo consiga ser difundido como uma alternativa de desenvolvimento. E que pode agregar benefícios, desde que planejado em parceria com setor privado e a comunidade. Há necessidade do compromisso das autoridades governamentais em se engajar e criar mecanismos de fomento ao turismo, até como forma de incentivar outros setores a investirem na atividade e consolidar Soure como um destino turístico.

A comercialização e a prospecção de novos negócios no setor turístico poderão proporcionar ao município aumento da oferta turística, com expressivos ganhos para os turistas e para a qualidade de vida das comunidades envolvidas. 


\section{REFERÊNCIAS}

- AULIC INO. M.D. Algumas implicações da exploração turística dos recursos naturais. In: RODRIGUES. A.B (org). Turismo e ambiente: Reflexões e propostas 3 ed. São Paulo: Huncitec, 2002.

- BENI. M.C. Análise Estrutural do Turismo. 10. ed atual. - São Paulo: SENAC,2004.

- BIN, J. Turismo sustentável. Disponível em: www.sustentabilidade.org.br, acesso em 28.11.2007.

- BOULLÓN. R.C. Os Municípios Turísticos. Tradução Carlos Valero - Bauru, SP: Educs, 2005

- BRAGA, D.C. Planejamento Turístico: Teoria e Prática. Rio de janeiro: Elsevier, 2007.

- BRASIL. Ministério da Saúde. Grupo Executivo Interministerial. Plano de desenvolvimento Territorial Sustentável para o Arquipélago do Marajó: resumo executivo da versão preliminar para discussão nas consultas públicas. Brasília: Ministério da Saúde, 2007.

- BRASIL. Ministério do Turismo. Programa de Regionalização do Turismo Roteiros do Brasil: Sustentabilidade ambiental -princípio fundamental - . Brasília,DF. ,2006.

- BRASIL. Ministério do Turismo. Programa de Regionalização do Turismo Roteiros do Brasil: Sustentabilidade Sociocultural - . Brasília,DF. ,2006.

- BRASIL. Ministério do Turismo. Programa de Regionalização do Turismo Roteiros do Brasil: Sustentabilidade Econômica:. Brasília,DF. ,2006.

- CASTELLI, G. Turismo e Marketing. Porto Alegre: Sulina, 1984.

- CASTELLI, G. Turismo: Atividade Marcante. Caxias do Sul: Educs, 2001.

- CONTI. J.B. A natureza nos caminhos do turismo. In: RODRIGUES, A.B (org) Turismo e Ambiente: reflexões e propostas 3.ed. São Paulo: Hucitec, 2002

- CRUZ, S. H.R. Os impactos do Turismo na llha do Marajó (PA): Aspectos ambientais da Praia do Pesqueiro. São Paulo Dissertação (Mestrado), 1998.

- DIAS. R. Turismo Sustentável e Meio Ambiente. São Paulo: Atlas, 2003.

- DIAS. R.; AGUIAR. M. R. Fundamentos do turismo: conceitos normas e definições. Campinas, SP: Alínea, 2002.

- ECONOMIANET. Conceito de Desenvolvimento Sustentável Disponível em http://www.economiabr. net/economia/3 desenvolvimento sustentavel historic o.htm acesso 08.01.2008.

- FERREIRA. E. C. S. O crescimento do turismo no Brasil. Revista Turismo, Disponível em <http://www.revistaturismo.com/artigos/crescimentobrasil.html> acesso: 16/01/2008. 
- FIGUEIREDO. S.J de L. Turismo e Cultura: mudança cultural em Soure [Marajó-PA] em decorrência da exploração do ecoturismo - Dissertação (Mestrado), 1998.

- FREIRE.C.A. Desafio é transformar Amazônia em produto. O liberal, Belém 3/2/2008. Caderno Atualidades. p.16

- LEMOS L. O Valor Turístico na Economia da Sustentabilidade. São Paulo: Aleph, 2005.

- LEMOS. L. O Valor Turístico: (RE) Definindo a Economia do Turismo. In BARRETO, M. (org); REJOWSKI, M. (org). Turismo: Interfaces e Incertezas. Caxias do Sul: Educs,2001.

- LEONY. A. Circuito do diamante: uma abordagem do ecoturismo na Bahia. . In: RODRIGUES. A.B.(org). Turismo e ambiente: Reflexões e propostas 3 ed - São Paulo: Huncitec, 2002

- LIMA, A.M.M; OLIVEIRA, L.L; FONTINHAS, L. R; LIMA, R. J. S. Ilha do Marajó: revisão histórica, hidroclimatologia, bacias hidrográficas, e proposta de gestão, 2005 disponível em:

<http://cece mca.rc.unesp.br/ojs/index.php/holos/article/view/331/290>. acesso em: $16 / 11 / 2007$.

- MAGALHAES. C.F. Diretrizes para o Turismo Sustentável em Municípios. São Paulo: Roca, 2002.

- MARAJÓ tem pouco ecoturismo, A ilha do Marajó - PA. Província, 2000.

- MARTINS, G.C.C. A dinâmica do turismo rural das fazendas pecuaristas da llha do Marajó - Dissertação (Mestrado), 2005.

- MARTINS, L. F. G. O Balanço de Pagamentos e o Turismo Internacional no Brasil. 2007.

- MENDES, R. A difícil escalada brasileira. In: Exame São Paulo ano 41, oㅡ 5 - São Paulo, 2007. (ISSN 0102-2881)

- MORHY, Érika. Turismo rural no Marajó. Beira do Rio on line, Belém, n. 37, fevereiro de 2005. Disponível em: <http: www.ufpa.br/ beiradorio/arquivo/beira37/noticias/noticia6.htm>. Acesso em: 16/11/2007

- ORGANIZAÇÃO MUNDIAL DO TURISMO. Guia de desenvolvimento do Turismo sustentável. tradu. Sandra Nertz. Porto alegre; Bookman, 2003

- PARATUR. Levantamento da Oferta Turística do município de Soure. BelémPA, 2001

- RICHARDSON, R. J. Pesquisa Social: métodos e técnicas. São Paulo: Atlas, 1985.

- RODRIGUES. A.B. Turismo e Geografia: reflexões teóricas e enfoques regionais. São Paulo: Huncitec, 1996

- RUSCHMANN, D. V. M. Turismo e Planejamento Sustentável . Campinas: Papirus, 1997.

- SANTOS. R. A.E. JR Transporte aéreo. Dimensões do desenvolvimento e da integração. In CARVALHO L. (org); BARBOSA, L.G. M (ORG). Discurssões 
e propostas para o turismo: observatório do turismo. Rio de Janeiro: SENAC Nacional, 2006.

- SCHULTER. R. O Desenvolvimento do Turismo Sustentável na América do Sul: O caso da Patagônia, na Argentina. In: PEARCE. D.G.; BUTLER. R.W (org) Desenvolvimento em Turismo: Temas Contemporâneos. São Paulo: Contexto, 2002.

- SINGH, T. V.; SINGH, S.O Turismo e as Tribos do Himalaia: em busca de opções de desenvolvimento sustentável para os Botias do vale Bhyundar. In: PERACE, D. W. Desenvolvimento em Turismo: temas contemporâneos. São Paulo: Contexto, 2002.

- SILVEIRA.M.L. Da Fetichização dos lugares a produção local do turismo. In: RODRIGUES. A. B (org). Turismo, Modernidade, Globalização. 2ed. São Paulo: Huncitec, 1999.

- SWARBROOKE, J. Turismo Sustentável: conceitos e impacto ambiental. São Paulo: Aleph, 2000.

- VELOSO. M.P. Turismo Simples e Eficiente: um guia com orientações básicas para municípios. São Paulo: Roca, 2003

- VERGARA. S.C. Projetos e relatórios de pesquisa em administração. São Paulo : Atlas , 2007. 


\section{APÊNDICE A}

Degravação das entrevistas realizadas no município de Soure.

Entrevista: João Lima

Data da entrevista: 30/01/2008

Local da entrevista: Eco Pousada Paracauary em Soure

Ocupação do entrevistado: Empresário e Presidente do Fórum de turismo do pólo Marajó.

\section{$\left.1^{\circ}\right)$ que o Sr. pensa do turismo no Marajó, especificamente em Soure, ele cresceu ou diminuiu ao longo desses anos?}

João Lima: Quando o turismo no Marajó era incipiente tava começando a movimentação era boa, quando eu digo boa era porque naquela época tinha poucas unidades hoteleiras. Hoje como houve uma multiplicação, hoje nós temos uma quantidade que pode parecer grande, mas não é tanto porque ela foi pulverizada. Antigamente o turismo se concentrava só em Soure,hoje não, já esta abrangendo mais Salvaterra. Quando nós tínhamos seis pousadas incluindo hotel em Soure. Hotel e pousada. Hoje nós temos mais de 25 contando Soure e Salvaterra, sem contar com a hospedagem nas fazendas que são outro departamento, vamos chamar só as pousadas urbanas.

Quando agente pensa será que aumentou o numero de turistas? na realidade hoje não aumentou, o que eu acredito todo o turismo em todo o estado do Pará ele decresceu, embora agente possa ver algumas algumas estatísticas, mas elas não são direcionadas elas são centralizadas. por exemplo agora até recente uma pesquisa da PARATUR, em bora ela se refira só a Soure mas por exemplo eu sinto no meu caso especifico, ate outras a título de outras pessoas também, outras pousadas que houve um decréscimo comparar por exemplo 2007 com 2006, 2007 foi mais fraco que 2006. Não se por exemplo em se tratando de Pará mais em termo de Marajó eu te garanto que foi isso aí.

Em termo de Marajó especificamente, não houve evolução, do meu ponto de vista houve uma "involução", quer dizer todos os números foram abaixo dos de 2006.

Então eu vejo agora, vamos considerar o marajó sendo Soure e Salvaterra ate porque quando se fala em turismo hoje no Marajó se fala de Soure e salvaterra 
embora comessem a fazer outros pólos, outras cidades mais hoje realmente é Soure e Salvaterra

Ai tu me perguntas o que que eu acho da evolução do turismo em Soure?

Eu acredito na evolução do turismo no marajó desde que sejam tomadas medidas bem direcionadas pro município, o que ta faltando na realidade são medidas políticas, agente tem um gargalo ou um calcanhar de aquiles como você queira chamar, nós temos lá não é ótima , não é boa é razoável, a estrutura hoteleira do Marajó, Soure e Salvaterra é razoável, eu te digo que poucos municípios do estado do Pará tenha a estrutura hoteleira que tem Soure e Salvaterra, é lógico tem muita coisa que não é legal, mas tem outras coisas que estão boas, legais mesmo. então agente tem lá o Hotel Ilha, a pousada dos guarás, modesta parte nós temos a nossa pousada, a pousada Boto, tem diversas pousadas que

Realmente da pra você ir, ficar bem acomodado sem nenhum problemas. Agora tem a necessidade de serem tomadas medidas de ordem governamental, porque o que na realidade nós não estamos querendo que o governo faça, nós queremos que o governo crie condições para que seja feito. Então por exemplo agente sabe que o gargalo ou o calcanhar de aquiles como queira chamar é uma coisa chamada é transporte. Porque eu entendo que eu não posso oferecer um turismo que eu não tenha uma estrutura razoável, é tipo aquela historia eu cobro caro porque não tenho demanda, eu não tenho demanda porque eu cobro caro, né a coisa é mais ou menos assim. Então agente sabe que o turismo no Marajó ta caro, nós sabemos. mas é exatamente em função dessa coisa a demanda é pouca, eu sempre costumo dizer, poxa, no Marajó é justamente o inverso dos outros setores, os outros setores trabalham onze meses e folgam um, aqui no Marajó é exatamente o contrario, agente trabalha um mês e folga onze. Eu tenho certeza que nos hotéis que você observou, alguns não tinha ninguém, em outros tinham 3 a 4 pessoas, né. Então quer dizer há necessidade de que agente, agente não, o governo crie condição pra que o turismo no marajó se desenvolva. Enquanto isso não for feito, a coisa realmente não vai acontecer.

Agora eu acredito que o governo deva tomar algumas providências em função do Fórum Estadual de turismo do estado do Pará, porque justamente esse fórum compõe o trade de belém, o trade de outras cidades outros municípios, no caso eu represento Soure e Salvaterra,o pólo atlântica, o pólo tapajós o pólo xingu, então tudo isso quer dizer o pólo Belém, tudo isso ai ta levando a direção de que o 
governo tome conhecimento daquilo que esta sendo feito, ta sendo pedido ta sendo colocado e tome as providencias.

Por que veja bem, aqui não vai uma critica ou algo direcionado a determinado governo. Se o governo de dois anos atrás não fez nada, eu não posso dizer que ele não fez nada, ele fez levantar toda uma estrutura veja bem, que até então nós não tínhamos, nós fazíamos um turismo de forma incipiente, deu, se não deu não dá. Mas ele fez um levantamento e achou que o turismo realmente seria uma atividade importante para o estado do Pará, mas só que no meu entendimento ele se esqueceu por qualquer motivo e esse motivo eu não sei te dizer quais são, mas ele deixou exatamente de criar uma estrutura de transporte. Então quer dizer hoje, lá no Camará pode ser vista a estação não é ótima, mas é boa, melhorou muito a estrada melhorou é uma estrada de qualidade. Em contrapartida os transportes que levam de Belém pra lá e Belém pra cá são precários como pode ser visto. outra coisa ai não esta incluído apenas quando eu me refiro a transporte eu quero me situar não só na questão do transporte fluvial mas,o rodoviário dentro da ilha. A qualidade do transporte é péssima, é terrível. Quando você a analisa o estado do Pará como um todo os problemas praticamente são os mesmos. No ultimo encontro dos fóruns que ocorreu os outros pólos reclamavam, do transporte, marcação turística centro de atendimento e informações ao turista é generalizado em todos os municípios do estado é isso aí.

Agora há cada um com sua peculiaridade, com sua situação, no caso especifico do Marajó é exatamente esse transporte, não vai me adiantar eu fazer uma estrutura excelente se eu não tenho uma demanda definida, não tem como eu fazer um investimento e depois não ter como eu pagar esse investimento.

Hoje a posição do turismo no Marajó é estanque, ela vai começar a andar quando o governo fizer a parte dele.

$2^{\circ}$ ) o que o Sr. acha da possibilidade de inserir o turismo como uma alternativa pro local de maneira sustentável?

Veja bem, se conseguir fazer o que tem que ser feito, o turismo passa a ser uma atividade principal. Porque veja bem, Soure e Salvaterra eles viveram um tempo atrás só da pecuária, que ainda vive e da pesca. o que nós temos hoje em Soure e Salvaterra não se iguala ao que era até o final dos anos 80 havia os grandes geleiros aqueles pescadores tradicionais, que possuíam dois barcos, um vinha pra 
Belém e outro ficava por lá. na realidade era isso que sustentava, era uma atividade que complementava exatamente a economia. porque a pecuária era toda voltada pra Belém, os grandes pecuaristas moravam em Belém. Eles vamos dizer tinham a mesma estrutura daquela época tem a mesma estrutura hoje, alguns realmente evoluíram procuraram melhorar. $\mathrm{E}$ isso não elevou o número de empregos. 0 gerador de emprego e renda praticamente ficou o mesmo. No meu ponto de vista hoje essas duas atividades a peca e a pecuária elas estão numa situação estanque elas não evoluíram e não vão evoluir mais do que foram, talvez possa diminuir mais evoluir dificilmente.

Então o que se tem pra fazer na realidade, qual a perspectiva de emprego hoje é exatamente o turismo, quer dizer agente tem uma estrutura de natureza que pode ser perfeitamente explorada não resta a menor duvida, tem praia , o produto turístico do Marajó é a praia fluvio -marítima, os únicos locais do mundo praia com água doce e com ondas.

Alguma pessoas questionam mas poxa nós temos que oferecer produtos diferente do que tem no nordeste, lá já tem praias, tudo bem mais as praias que tem lá são diferentes das que tem aqui. Então quer dizer seria o produto turístico praia de água doce e salgada e tem os períodos que fica salobra e a questão do ecoturismo.

Eu vejo no turismo a possibilidade, ressaltando desde que o governo de as condições. até porque nós temos um mercado próximo. O Marajó tem um mercado próximo chamado Belém, e no momento que esse mercado começar a se voltar pra lá. Nós temos uma demanda natural, eu não vou precisar vender meu produto lá no Rio Grande do Sul, Rio de Janeiro, São Paulo, porque eu tenho uma demanda aqui. Sabe que o paraense ele é muito chato, pela experiência que eu tenho nesse tempo que eu tenho uma pousada. Ele ta acostumado a fazer Salinas, Mosqueiro, saindo de casa de carro vai e volta a gora que quer. E lá pro Marajó não é possível, mais em contra partida agente pode dar a esse turista um transporte digno. Eu sempre penso o seguinte, vamos fazer uma programação, final de semana eu vou a Salinas, mas pra salinas são 400km pra ir e voltar vou ter que dirigir $3 / 4$ hora. Ma se tiver um barco que me leve no Marajó em 1 e meia ou 2 horas, eu saio de Belém 6:30 e chego 8:30 e saio da daqui 17:30 chego a Belém 19:00 passei um dia legal, até porque lá teria que se criar uma estrutura de transporte interno, para pegar esse turistas de Belém e levar até as praias pra conhecer exatamente o que tem lá. 
eu acredito que o máximo que levaríamos para ganhar esse mercado de Belém, seriam seis meses, agora não levaria no inverno, teria que levar exatamente de maio em diante. Eu vejo como boa perspectiva o turismo lá, desde que o governo faça a sua parte, não é fazendo as coisas é dando condições, ai você pergunta que condições seriam estas faz a infra estrutura e abre licitações de transporte para o Marajó bota as condições do tipo de transporte que era e estará resolvido o problema. porque se por uma acaso os empresários da área disserem que tão tendo prejuízos é mentira porque eles não estariam mais aqui, eles não ficariam no prejuízo esse tempo todinho. Então basta que realmente bote um transporte legal e tudo estará resolvido.

Numa reunião que eu tive na PARATUR, eu falava exatamente da possibilidade de aproveitar e recuperar o navio Soure que foi construído com as características para atravessar essa baía, que fazia a viagem direta, esse navio foi construído com esse fim, mais ou menos na década de 80. Eu acho que se o governo do estado pegasse o navio enchesse de gente, porque o negócio é urgente. Hoje as agências de turismo de Belém não estão vendendo o Marajó, o pessoal que está comprando, porque veja bem, você pode classificar de duas formas, que eu entendo, vender é quando eu te ofereço o meu produto, mas tu chega sem eu te dizer nada, Lima tu pode me vender uma diária, na tua pousada tu tá me comprando eu não tô te vendendo, eu defendo a coisa dessa forma. Então o momento que o governo do estado fizer a parte dele, abrir licitação, coloca as medidas que tem que ser feitas para uma embarcação dessa e a coisa vai andar, com certeza.

Eu te afirmo o turismo é a solução pro Marajó, porque o turismo é a atividade que mais distribui renda, porque eu tenho os funcionários se eu tiver uma demanda muito grande eu vou ter que colocar gente pra ajudar, ai eu vou ter que utilizar a fazenda, vou ter que levar o pessoal na praia, lá eles consomem, os que vão para as fazenda vão consumir e vou ter que pagar o passeio pra fazenda, ele vai sair pra tomar um cerveja no bar porque não vai ficar o tempo todo dentro da minha pousada. Então quer dizer pulveriza ai, o meu empregado vai comprar a comida dele no açougue ou supermercado, comprar roupa. Da onde ele vai tirar? Então ele fica trabalhando comigo. Aquele barraqueiro ele ta recebendo de turistas, ele ta pegando o dinheiro dos turistas pra comprar as necessidades dele. e essa é a atividade que mais distribui renda. 


\section{De que forma o PROECOTUR atuou no Marajó, o que foi o programa para o município?}

Se nós levarmos para o lado do investimento financiado, pouca coisa foi feita ou quase nada. até porque se agente olhar o lado empresarial talvez não tenha havido uma divulgação de dizer olha gente se arrumem que o banco vai financiar vocês, talvez não tenha havido esse chamamento para o empresariado não deram o conhecimento para o empresariado, então se tu ouviste dizer que o PROECOTUR aqui não funcionou, te digo que não funcionou. a coisa não aconteceu como deveria acontecer.

Nem através do Fórum de turismo, que o sr. é presidente, não foi repassado nada?

Não, porque veja bem, dentro dessa área hoje, o fórum de turismo foi criado a um ano e nós não temos nada a respeito disso ai. Hoje não, da criação do fórum pra cá nada. Quem sabe se agora dentro dessa nova estrutura, eu li no jornal que o governo federal tinha destinado recursos pro Marajó, pra Belém, para alguns pólos. Quem sabe se dentro dessa divisão, desse bolo de recurso que tá sendo distribuído /destinado pode ser que tenha alguma coisa.

\section{o Sr. tem conhecimento dos trabalhos,de divulgação de Soure que está sendo realizados seja pela secretaria de turismo ou por outros meios?}

A promoção de Soure hoje está sendo feita através do site de Soure, fora disso ai cada um esta se divulgando na internet, por conta própria, não há por parte do município uma divulgação das ações do município em relação ao turismo.

No ano de 2000, o SEBRAE foi o indutor do aumento de pousadas no Marajó, através de uma perspectiva que foi criada. Então, chegaram no Marajó (Soure Salvaterra) o SEBRAE e a PARATUR dizendo exatamente o que ia ser feito. $O$ pessoal se danou a fazer pousada aqui, febre de pousada. Hoje ninguém ta fazendo mais porque tá tudo vazio. Então o que foi que aconteceu? A PARATUR com o SEBRAE chegou e disse olha, o turismo daqui pra frente vai deslanchar e as pessoas que tinham terrenos começaram a construir pousadas, ai o que aconteceu, não aumentou o fluxo, a demanda, pelo contrário, a demanda pode ter permanecido a mesma ou diminuído e ela foi toda fragmentada. Em 2005 e 2006 a taxa de 
ocupação tava na faixa de $40 \%$ a $65 \%$, em 2007 a faixa era de $10 \%$ a $25 \%$. Essa é a realidade.

\section{Qual o papel do Fórum, porque tem a secretária de turismo?}

$\mathrm{Na}$ realidade, o papel do Fórum nada mais é do que o órgão de articulação, no sentido de desenvolver o turismo, dar sugestões mais ou menos assim.

\section{Mas e a secretaria de turismo não seria isso também?}

Não, ela executa, o fórum não executa, ele mobiliza se for o caso ele pode apresentar projetos, sugerir determinadas ações, mas ele não pode executar essas ações. O Fórum é uma espécie de intermediário entre o município no caso a secretaria de turismo, entre a PARATUR até chegar no ministério do turismo. Qualquer município que tenho o fórum ele tem que pegar o projeto, encaminhar para o fórum, encaminha para PARATUR, que encaminha para o ministério do turismo, ele que define a coisa, com verba do ministério fórum é uma organização exatamente de mobilização dos outros órgão, a própria secretaria de turismo e a comunidade no sentido de ficar sempre envolvida

\section{Entrevista: Dário Pedrosa}

Data da entrevista: 26/01/2008

Local da entrevista: Secretaria de Turismo de Salvaterra

Ocupação do entrevistado: Secretário de educação do município. :

\section{Como você analisa o turismo no Marajó de uma forma ampla?}

O produto Marajó não esta acabado. O turismo na região se limita a visitas a s praias, algumas fazendas e centros de comercialização de artefatos de couro, cerâmica e sementes.

As ruínas de Joanes, as comunidades quilombolas, a pesca esportiva como o tucunaré, a focagem de jacaré, o turismo de aventura, 0 arborismo, trilhas ecológicas, todas estas opções ainda não foram exploradas como deveria, de maneira sustentável, responsável e profissional. Precisamos dinamizar o produto Marajó no contexto da oferta de opções para que o visitante possa melhor aproveitar seu tempo aqui e assim sentir a necessidade de permanecer mais entre nós, além de envolver mais pessoas na oferta destes serviços e adereços do produto. 


\section{Na sua opinião qual a grande dificuldade para o município sar do status de potencial para real?}

Sofremos com o pouco de turismo que temos pela má qualidade dos serviços ofertados. Poucos hotéis possuem equipes profissionais de atendimento ao público, a maioria dos estabelecimentos são gerenciados e formados por equipes de serviços ligados a família do proprietário para diminuir despesas e reter entre a família o máximo dos lucros com o negocio a revelia da qualidade pelo atendimento depreendido a quem vem em busca do serviço, o turista.Como se não bastasse a maioria destas pessoas já envolvidas no processo se abstém de participar dos cursos de capacitações ofertados por órgão como a Paratur, Sebrae, ETPS e outros, mesmo tendo participado de pesquisas de levantamento de demandas de capacitações para serem ofertadas, pois apenas apontam a falha de seus concorrentes e não observam os seus, e também por não acreditarem na importância desta capacitação para melhorar objetivamente os lucros de seus negócios.

A informalidade dos estabelecimentos é outro grande problema, a maioria dos hotéis e restaurantes não possuem Pessoa Jurídica constituída o que os impede de participar de programas de incentivo ao turismo regional como é o caso do SERVITUR, criada pelo Governo do Estado para incentivar o turismo dos servidores do Estado, com financiamento pelo Banpará.

Há uma grande resistência por parte dos proprietários em regulamentar o estabelecimento, porque terão que pagar mais impostos e eles não querem gastos, não procuram investir no seu estabelecimento, capacitando as pessoas que trabalham recepcionando diretamente o turista.

\section{Entrevista: Maria Algina Soares Silva}

Data da entrevista 11/02/2008

Local da entrevista: SEBRAE/ PA

Ocupação da entrevistada: Gestora de Turismo SEBRAE/PA e coordenadora do Projeto Turismo Amazônia do Marajó, baseado no Programa de Regionalização Turística do Ministério do Turismo. Realizado nos municípios de Soure e Salvaterra na Iha do Marajó-PA nos período 2005 a 2007. 


\section{De que forma o Sebrae contribuiu para o desenvolvimento do turismo no município de Soure?}

O Programa desenvolvido pelo Sebrae estava voltado para ações realizadas no sentido de disseminar a cultura empreendedora através das capacitações com orientações específicas mercado, priorizando a qualidade no atendimento, a melhoria constante dos equipamentos e serviços, transporte, hospedagem e alimentação. Todo o projeto foi pautado no processo de participação dos atores locais, através de encontros com os empresários, principalmente, no planejamento das diretrizes das ações para o desenvolvimento sustentável da atividade turística.

Dentro do programa também foram realizadas ações de roteirização turística e a formatação de produtos para serem apresentados no Salão de Turismo, dentre eles a comunidade de Pesqueiro, em Soure. No sentido de indicar sugestões de passeios a serem realizados nos municípios de Soure e Salvaterra evidenciando os atrativos naturais e culturais dos municípios.

Vários circuitos foram criados dentro do município de Soure e Salvaterra pois o projeto elaborou um circuito integrado, como: circuito gastronômico, circuito de lazer, circuito dos rabeteiros, circuito turismo rural, city tour.

Esses roteiros foram trabalhados durante o período de realização do projeto 2005/2007, junto com os empresários e a comunidade local. Entretanto, não posso afirmar se os circuitos estão funcionado até hoje, o projeto foi encerrado em julho de 2007 e não houve nem nenhum acompanhamento de julho pra cá.

O grande problema para o desenvolvimento do turismo no Marajó é a grande resistência por parte dos proprietários dos estabelecimentos em melhorar o turismo na região. Desde de 2003 são realizados projetos com parceria do Sebrae no sentido de promover o turismo no município. Mas pouca coisa mudou em nesse período (2003 - 2007), os resultados não aparecem e isso compromete a credibilidade de investir no município.

Além do mais, o transporte e a infra-estrutura deixam muito a desejar. Já passei por problemas voltando de Soure a trabalho, o barco ficou por alguns minutos a deriva no meio da baía, fiz denuncias,mas não deu em nada. As coisas não mudam. Não há um interesse em melhorar o turismo.

Os empresários locais têm outro problema, não entendem que o turista de Belém é que vai sustentar o turismo no município, mais eles preferem os turistas estrangeiros, por isso cobram preços altos e ainda dizem que o turista de Belém é 
muito exigente, mas o exigente que eles se referem é pelo fato de que os belenenses conhecem a região e não admitem ser enganados, pagando preços altos e recebendo serviços de baixa qualidade.

O turismo no Marajó está sendo um trabalho muito difícil.

\section{E as agências paraenses não se interessam em se juntar com o SEBRAE e divulgar o destino Marajó?}

São poucas a s agências que comercializam o produto Marajó, e além do mais os empresários de Soure não gostam de ter seus serviços de hospedagem vendidos pelas agencias, porque elas cobram uma taxa de serviço que eles não querem pagar. Preferem divulgar a seu modo, cada um por si, mas desse jeito fica quase impossível o turismo se desenvolver.

\section{Como você v o turismo hoje em Soure?}

O Turismo em Soure já teve o seu grande momento quando foi criado o ministério do turismo e o programa de roteirização. Antigamente quando se fazia viagem para Soure era possível encontrar muitos turistas, hoje em dia são raros a maioria das pessoas que vão pra Soure são os moradores que estavam em Belém ou profissionais que vão a trabalho. O turismo caiu muito, não só na nossa região, eu acredito que no Brasil como um todo, não tenho como mostrar isso através de dados porque nunca fiz uma pesquisa, mas as viagens que realizei ano passado eu pude verificar o fluxo de turistas, exemplo disso foi Natal já fui várias vezes no mês de novembro e ano passado notei que a demanda estava menor. $E$ isso ta ocorrendo em todo Brasil e na nossa região ainda mais, principalmente porque viajar pra cá é caro e as pessoas precisam entender que temos algumas particularidades.

Percebo que principalmente os turistas do Sul e Sudeste tem preconceitos em relação ao Norte do país, eles tem que entender e também tem que haver mais informações sobre o turismo na região, aqui não é como pro sul que tu é interligado por rodovias, aqui existem muitos rios que servem de caminhos para se chegar a alguns municípios do interior do estado. Não da pra conhecer o Marajó em 1 dia, até dá se for de táxi aéreo, mas nem todos têm bancar esse custo, pra maioria é inviável. Falta informação em relação nossos produtos e as características da região. 